\title{
Siberian spruce tree ring anatomy: imprint of development processes and their
}

\section{high-temporal environmental regulation}

Elena A. Babushkina, ${ }^{\mathrm{a}}{ }^{*}$, Liliana V. Belokopytova ${ }^{\mathrm{a}}$, Dina F. Zhirnova ${ }^{\mathrm{a}}$, Eugene A. Vaganov ${ }^{\mathrm{b}, \mathrm{c}}$

${ }^{a}$ Khakass Technical Institute, Siberian Federal University, 27 Shchetinkina, 655017, Abakan, Russia

${ }^{\mathrm{b}}$ Siberian Federal University, 79 Svobodny, 660041, Krasnoyarsk, Russia

${ }^{c}$ Sukachev Institute of Forest, Siberian Branch of the Russian Academy of Sciences, 50/28

Akademgorodok, 660036, Krasnoyarsk, Russia

* Correspondent author

E-mail address: babushkina70@mail.ru

\begin{abstract}
Due to its advantages in terms of much longer cover period and less demanding measurements, wood anatomy of Picea obovata Ledeb. was offered as spatiotemporal proxy record for tracheid differentiation kinetics. In this study, external and internal regulation of earlywood-to-latewood transition and properties of latewood were considered. The values and interrelations between cell number, tree ring width, maximal and mean radial cell diameter, maximal cell wall thickness and position of the transition to thick-walled tracheids were investigated within site and along the altitudinal gradient. Correlations with moving 21-day climatic series were used to estimate high-resolutional external influences. Relationships between tree ring traits are spatially stable and close within one stage of differentiation and between cells production and expansion. Relationships between sites differ in upper and lower parts of the gradient. Most of traits respond to the primary limiting factors near summer solstice; however, maximal cell wall thickness responds positively to the temperatures at the $+10^{\circ} \mathrm{C}$ threshold. Altitudinal anatomical patterns revealed interaction of intrinsic and external factors in the regulation of tracheid differentiation. Timing of climatic response highlighted role of photoperiod as a trigger in the earlywood-to-latewood transition, and crucial role of the growth season ending for latewood development.
\end{abstract}

Keywords: altitudinal gradient; Picea obovata; digital wood anatomy; tracheidogram; cell chronology; climate-growth relationship 


\section{Introduction}

The division of conifer tree rings into earlywood and latewood tracheids during the process of their differentiation remains the subject of intense research in both anatomy and physiology. The thick-walled latewood cells are suggested as necessary to ensure the mechanical strength of wood tissue and the tree as a whole (Brown et al., 1949; Zobel and van Buijtenen, 1989; Gartner, 1995; Yasue et al., 2000; Hannrup, 2001; Bowyer et al., 2003; Sperry et al., 2006; Björklund et al., 2017). However, examples of many tree species raise questions about such suggestions, particularly in the tropical zone; in these examples the number of such tracheids can be very small or zero (Vaganov et al., 1985; Schweingruber, 1990; Russo et al., 2010; Zhang et al., 2017). The hypotheses of seasonal switching of processes appear to be more attractive. For example, at the beginning of the vegetative season, a tree experiences high demand for water and minerals for growth of shoots and the assimilation apparatus, imposing requirements on the hydraulic characteristics of the emerging tracheids. Subsequently, after cessation of primary growth, the water demand is significantly reduced and the production of assimilates becomes sufficient for their active deposition in the cell walls, i.e. development of thick-walled tracheids (Moehring et al., 1975; Antonova and Stasova, 1997; Hansen et al., 1997; Plomion et al., 2001; Uggla et al., 2001; Simard et al., 2013; Olano et al., 2014; Petit and Crivellaro, 2014). Another hypothesis concerns the possibility that the processes of cell expansion and cell wall thickening are regulated by photoperiod, indicating that decreasing day length is a trigger for switching to latewood cell development (Heide, 1974; Gyllenstrand et al., 2007; Asante et al., 2011; Karlgren et al., 2013; Petterle et al., 2013; Jyske et al., 2014). In any case, intrinsic mechanisms of seasonal switching include both hormonal control and differentiated expression of key genes responsible for the activity of enzymes involved in latewood tracheid maturation (Wareing and Phillips, 1970; Lindström, 1997; Uggla et al., 1998; Schrader et al., 2003, 2004; Cato et al., 2006; Gyllenstrand et al., 2007; Hölttä et al., 2010; Zobel and Jett, 2012; Petterle et al., 2013). As a result of external and internal control of conifer tree ring development, changes in cell radial size and wall thickness along the ring are smooth and gradual and therefore cannot be fully described with simple Mork's dividing into earlywood and latewood tracheids (Mork, 1928; Denne, 1989; Rozenberg et al., 1999; Sviderskaya et al., 2011; Babushkina et al., 2018a). This fact is supported by numerous wood cell morphometric measurements, including automated ones (von Arx and Carrer, 2014; Gärtner et al., 2015; von Arx et al., 2016; Prendin et al., 2017; Peters et al., 2018). 
Because of the increased interest in the kinetics of seasonal tree ring development in various climatic conditions, some generalizations have been developed about durations and rates of the primary processes of tracheid differentiation (Horacek et al., 1999; Rossi et al., 2006a, 2011; Camarero et al., 2010). For example, contribution of these kinetic characteristics to cell expansion and wall thickening stages of tracheid differentiation was evaluated for several conifer species (Skene, 1969; Dodd and Fox, 1990; Cuny et al., 2013, 2014). For the cell expansion result, $75 \%$ is determined by the duration and $25 \%$ by the rate of this process, whereas in the cell wall thickening, the contributions of duration and rate are approximately the same (Denne, 1972; Anfodillo et al., 2012; Cuny, 2013). The evaluation of the residence time for each tracheid in the zones of cell expansion and cell wall thickening was an important result of kinetic research (e.g. Rossi et al., 2006b; Balducci et al., 2016; Deslauriers et al., 2017). In this regard, the duration of cell wall thickening for latewood tracheids can reach 45-50 days or even more (Rossi et al., 2006b; Cuny et al., 2013; Kraus et al., 2016; Mäkinen et al., 2018). In the conditions of a short growth season at the treeline at high latitudes and altitudes and particularly over extreme years in terms of heat supply, a premature stopping of the cell wall thickening process occurs in the last tracheids, leading to the development of less thick-walled cells (cf. Rossi et al., 2006a, 2008; Lupi et al., 2010).

These kinetic patterns of tree ring development were obtained from direct measurements with periodic sampling of micro-cores from living trees over the growth season during several years (Rossi et al., 2007; Li et al., 2012; Cuny et al., 2014; J. Zhang et al., 2018). This process is not only labourious and time-consuming but also does not cover the entire range of variation in climatic conditions during the tree life span. Increase in the duration of observations helps to expand this range, but only within the current climate, without taking into account long-term changes, which limits the use of this approach.

The abovementioned studies of seasonal growth kinetics are performed according to the following scheme: current climatic conditions - traits of kinetics (seasonal measurements) - particular anatomical structure of tree rings. The traits of this anatomical structure that originate from each of the three primary tracheid differentiation processes can be selected and therefore used as a proxy of their kinetics: 1) tree ring width and cell number for production; 2) the radial dimensions of the tracheids for expansion; 3) cell wall thickness for deposition of the secondary cell wall (Larson, 1994; Vaganov et al., 2006; Deslauriers et al., 2017). Therefore, in this study, we propose to use the reverse research scheme: climatic conditions during long-term observation period - traits of the tree ring anatomy - an indirect estimate of growth kinetics (Carrer et al., 2017; Castagneri et al., 2017; von Arx et al., 2018). 
Within this scheme, the comparison of the long-term dynamics of climatic factors and of wood anatomical traits for trees growing along an altitudinal gradient may allow for an indirect assessment of the effect of the growth season duration on tracheid differentiation and examination of the hypothesis of regulating the cell wall thickness in latewood by the timing of the growth season end. The relative position of the transition to thick-walled cells as a quantitative indicator of seasonal switching of tracheid differentiation processes from earlywood to latewood was also of interest.

\section{Materials and Methods}

The study was conducted on the Borus Ridge of the Western Sayan Mountains, on the southern border of the Khakass-Minusinsk depression (Fig. 1). The foothills have an altitude of 300-400 $\mathrm{m}$ a.s.1., and the highest altitude is $2318 \mathrm{~m}$ a.s.1. A wide range of elevations results in a variety of vegetation; however, conifer forests consisting of the following species cover most of the area: Scots pine (Pinus sylvestris L.), Siberian pine (Pinus sibirica Du Tour), Siberian larch (Larix sibirica Ledeb.), Siberian spruce (Picea obovata Ledeb.) and Siberian fir (Abies sibirica Ledeb.). Soils are loamy, thin and stony, with numerous hard rock outcrops. The depth and fertility of the soil layer vary greatly depending on the local terrain.

For this study, we used daily mean air temperatures and amounts of precipitation according to the weather station in Cheremushki $\left(52.87^{\circ} \mathrm{N}, 91.42^{\circ} \mathrm{E}, 330 \mathrm{~m}\right.$ a.s.1.), which is located in the foothills $4 \mathrm{~km}$ to the northeast of the Sayano-Shushenskoe Reservoir dam. To use in dendroclimatic correlation analysis, we calculated moving series of temperature and precipitation with a 21-day window and 1-day step (i.e. from May 1 to May 21, then from May 2 to May 22, etc.) from daily data. These moving series has the same time span as the original daily series and cover the total length of a 50-year period of anatomical measurements (1965-2014). A similar approach with various window widths from 10 to 30 days has previously been used to analyse the climatic signal with fine temporal resolution in the season, both in tree ring width and in wood anatomy (e.g. Helama et al., 2016; Carrer et al., 2017; Castagneri et al., 2017; Belokopytova et al., 2018a, 2018b).

The regional climate is sharply continental, with large daily and seasonal temperature fluctuations and with uneven distribution of precipitation throughout the year. At the foothills, temperatures are negative from November to March; the average temperature of this period is $8.3^{\circ} \mathrm{C}$ below zero, and the average amount of precipitation is $74 \mathrm{~mm}$. The average temperature of the warm season (April-October) is $11.6^{\circ} \mathrm{C}$ above zero, and the average amount of precipitation is $485 \mathrm{~mm}$. As the altitude increases, temperature decreases throughout the entire year; the lapse rate is $c .0 .4-0.6^{\circ} \mathrm{C}$ per $100 \mathrm{~m}$, depending on the season. 
By contrast, the amount of precipitation increases rapidly with the altitude: approximately threefold more precipitation occurs at the upper tree line (1300-1400 m a.s.l.) than at the foothills.

During the period of instrumental climatic observations, precipitation did not change significantly, but temperature increase was observed of 0.2 and $1.1^{\circ} \mathrm{C}$ per decade during warm and cold seasons, respectively. The climate of the last decades was greatly influenced by the construction of the Sayano-Shushenskoe Reservoir dam and the filling of the reservoir during 1975-1990. The primary effect is expressed in the alleviating of winter frosts. More detailed data on regional climate change and local impact of the dam building are presented in the previous study (Babushkina et al., 2018b).

We sampled the cores of Siberian spruce (Picea obovata) in the National park 'Shushensky Bor' at three sites along an altitudinal gradient: $\mathrm{LOW}\left(52.83^{\circ} \mathrm{N}, 91.45^{\circ} \mathrm{E}, c\right.$. $520 \mathrm{~m}$ a.s.1.), at the lower boundary of the spruce distribution range; MID $\left(52.80^{\circ} \mathrm{N}, 91.48^{\circ}\right.$ E, c. $960 \mathrm{~m}$ a.s.l.), in the centre of the spruce range; and $\mathrm{HIGH}\left(52.81^{\circ} \mathrm{N}, 91.51^{\circ} \mathrm{E}, c .1320 \mathrm{~m}\right.$ a.s.1.), on the upper tree line. The site selection was conditioned by the requirements of logistic accessibility. All sites are located in 5-10 km to the east of the dam (Fig. 1). We can assume that influence of reservoir decreases with distance and elevation (i.e. from station to the HIGH site), but distances are close enough to disregard this pattern. The status of the territory as a protected area ensured minimization of human impact on vegetation, except for the local climatic change. Poor logistic availability of study area makes it less convenient for people to use than other forests of region, and Siberia never had high density of population. Therefore, human activities registered in the area are limited to tourism since 1960th and hunting by local nomads before 20th century; logging and other forest management activities were not registered (personal communication with Tolmachev V.A., national park director; see also Myglan, 2010 and references there). A fir-birch forest with Siberian pine and Scots pine covers the LOW site; spruce grows along a stream and on the adjacent northern slope. The MID site is covered by Siberian pine forest with Scots pine and spruce (c. 10\%); the slopes are east and west-oriented. The upper tree line (HIGH) is also covered by Siberian pine forest; spruce grows in a flat area near a stream and on the eastern stony slope. Landscape-soil conditions at all altitudes are heterogeneous even on a local scale.

We estimated inter-annual temperature dynamics at the elevations of the sampling sites based on the data of the Cheryomushki and Olenya Rechka $\left(52.80^{\circ} \mathrm{N}, 93.23^{\circ} \mathrm{E}, 1400 \mathrm{~m}\right.$ a.s.1.) weather stations (Supporting Information Fig. S1), because the temperature series of both stations have very close correlations (0.80-0.97), and no longitudinal temperature 
gradient was observed for the region. Average estimation of the vegetative season $\left(\mathrm{T}>+5^{\circ} \mathrm{C}\right)$ for 1965-2014 was 166 days (Apr 24-Oct 6) at the LOW site, 142 days (May 9-Sep 25) at the MID site, and 121 days (May 19-Sep 17) at the HIGH site. Temperatures above the $+10^{\circ} \mathrm{C}$ threshold occurred on 119 days (May 17-Sep 14), 93 days (Jun 1-Sep 1), and 75 days (Jun 11-Aug 24) at LOW, MID and HIGH sites, respectively.

For sampling, we selected living, undamaged trees, at least 20 trees per site, and cores were taken with an increment borer at chest height $(c .1 .3 \mathrm{~m})$. For collection, transportation and preparation of the cores for tree ring width (TRW) measurement, we used standard techniques of dendrochronology (Cook and Kairiukstis, 1990). For each tree, we measured TRW series with the semi-automatic analysis platform LINTAB 5 and TSAPwin software (Rinn, 2003) and verified the cross-dating of series in COFECHA (Holmes, 1983). Then, using the ARSTAN program (Cook and Krusic, 2005), we standardized TRW measurements (removed long-term non-climatic trends fitted as exponential functions) and developed local standard chronologies from individual series with a bi-weighted mean. When selecting cores for anatomical measurements ( 5 cores from each site), we preferred the mature trees with high correlation of the individual indexed TRW series with local chronology, which allowed for the minimization of age trends in TRW and particularly in the anatomical structure of tree rings over the period under consideration (Vysotskaya and Vaganov, 1989; Lei et al., 1996; Eilmann et al., 2009).

From the cores selected for anatomical research, we cut thin cross-sections (c. 15-20 $\mu \mathrm{m})$ with a sliding microtome (Microm HM 430; Thermo Fisher Scientific, USA) and stained them with safranin (1\% solution in ethanol). Then, we dehydrated the cross-sections using ethanol solutions with increasing concentrations, washed them with xylol, and permanently preserved them in Canada balsam. We captured microphotographs of prepared sections with a digital camera (AXIOCam MRc5; Zeiss, Germany) mounted on an optical microscope (Axio Imager D1; Zeiss, Germany) with 200× magnification. For anatomical structure analysis, we measured tree rings over the period 1965-2014 (50 years) with Lineyka 2.01 software (Silkin, 2010). Cell number (N), radial diameter (D) and wall thickness (CWT) were measured of each cell for five radial files per ring (Seo et al., 2014) to within $0.01 \mu \mathrm{m}$ (Vaganov et al., 1985; Larson, 1994). Additionally, we calculated TRW individual series as the sum of D for all cells and used it for cross-dating of anatomical measurements. To compare series and rings with different cell numbers, we subsequently normalized (stretched or compressed) raw measurements of D and CWT, obtaining their normalized tracheidograms with $\mathrm{N}=15$ (Vaganov et al., 1985; Babushkina et al., 2010; Ziaco and Biondi, 2016). The normalized 
number of 15 cells per ring was chosen to avoid possibility of distortion in climatic signal due to stretching tracheidograms more than twice in more than $10 \%$ of rings (calculated at site with minimal cell number; for reasoning see Electronic supplementary material in Belokopytova et al., 2018b), and as a value that proved to provide reliable results. For each ring, we then calculated the following tree ring features on the normalized tracheidograms: maximal and mean radial cell diameter (Dmax, Dmean), maximal cell wall thickness (CWTmax), and the relative position of the transition to thick-walled cells (Supporting Information Fig. S2). For spruce in the study area, the fraction of earlywood cells exceeded $1 / 3$ in most rings (>95\%). Therefore, we used the arithmetic mean CWT for the first four normalized cell positions CWTmean $_{1-4}$ as the CWT estimation for earlywood. Value 1.25. CWTmean CW $_{1-4}$ was applied as the threshold for thick-walled cells, coefficient 1.25 was selected empirically as minimal value providing assessment of stable CWT increment (probability of CWT falling back under this threshold is $\mathrm{p}<0.01$ over all measured tree rings). Then, we found the first normalized position of the CWT stably exceeding this threshold (Pos) and used it as an estimation of the transition to thick-walled cells. Based on individual series of anatomical traits, we then developed their average local chronologies (Fig. 2).

In this study, we used the following statistical characteristics of the series and chronologies: arithmetic mean, standard deviation, coefficient of variation (ratio of standard deviation to mean value), and first-order autocorrelation. The relationships between tree ring traits and their climatic responses were estimated by Pearson's correlation coefficients, and some of relationships were modelled by simple linear regressions.

\section{Results}

The TRW dependence on the cell production trait $\mathrm{N}$ at all three elevations is very close to a linear function both for individual trees and on a local scale (Fig. 3). This finding is confirmed by linear regression models TRW(N) determination coefficient values of 0.90-0.99 for individual trees (mean values are about 0.96 at each site) and 0.96-0.97 for total site samples (Supporting Information Table S1). The intercept for all functions is close to zero, i.e. the relationship between these tree ring features is close to directly proportional. As a result, we can interpret the linear regression coefficient as an estimation of the average cell radial diameter for an individual tree or for a site. Comparison of these coefficients showed that at MID and HIGH sites the average cell diameter is 25.9-33.2 and 25.6-33.3 $\mu \mathrm{m}$, respectively, i.e. the differences in diameters are not significant. Similarly, at both elevations, the maximal cell production is within 50 cells per season, with mean amount $\sim 20$ cells. However, at the lower boundary of the spruce range, much larger production (up to 180 cells 
per season, mean amount $\sim 60$ cells) is combined with the development of larger cells (average radial diameter is 27.3-36.4 $\mu \mathrm{m}$ ). Note that both mean values and variability ranges of the Dmean as individual or local characteristics of spruce trees are somewhat lower than those of other conifers in the region. For example, in previous studies of Scots pine and Siberian larch in the forest-steppe zone of the Minusinsk depression, we observed average radial diameter of the tracheids within the range of 34.0-42.1 and 31.7-43.7 $\mu \mathrm{m}$, respectively, and the coefficient of determination for the local TRW $(\mathrm{N})$ dependence is about 0.89 for both species (Belokopytova et al., 2018b). However, the intercept of the linear regression is low but not equal to zero, therefore this cell size estimate differs from the mean value calculated for the individual and local chronologies of Dmean (Table 1). In this study, the deviations have different signs and reach $6 \mu \mathrm{m}$.

Other cell traits also have their patterns of distribution within a site and along the altitudinal gradient. The maximal cell radial diameter Dmax, similar to Dmean, has close values and variability ranges at the HIGH and MID sites but is significantly greater (by $5.7 \mu \mathrm{m})$ at the LOW site. For both traits concerning the results of cell wall deposition, the variation is much higher. We observed similar values of these cell traits at the MID and LOW sites $(\mathrm{CWTmax} \approx 4.6 \mu \mathrm{m}$ and Pos $\approx 8)$, whereas at the HIGH site we can see a smaller fraction of latewood (i.e. larger value of Pos $\approx 9$ ) with less thick-walled tracheids (CWTmax $\approx$ $3.4 \mu \mathrm{m})$. Note also that chronologies of cell maximal and mean radial diameters have much less variation (3.9-6.7\% and 5.1-6.6\%, respectively) in comparison with CWTmax and Pos (9.9-11.5\% and $11.3-11.7 \%$, respectively).

For all considered tree ring features, there are some differences between individual trees both in mean values and in the inter-annual dynamics. As a consequence, the coefficient of variation for local chronologies is lower than that for most of the individual series. However, common external signal is present in all considered tree ring features, because the correlations of their individual series with local chronologies are all positive and significant (Table S2). We observed the highest individual-to-local correlations in the Dmax and Dmean series (0.51-0.59 and 0.53-0.61, respectively).

Autocorrelation component decreases from TRW (first-order autocorrelation $~ 0.7$ ), maximal and mean radial diameters ( 0.6) to CWT and Pos site chronologies (0.3-0.5), but difference between sites is not significant.

Common variance is less pronounced for trees growing at different elevations (Table 2). For example, a significant similarity in the radial cell diameter dynamics is present only between LOW and MID sites for which correlations are 0.58 for Dmax and 0.50 for 
Dmean. By contrast, CWTmax and Pos have close correlations only between MID and HIGH sites $(0.54$ and 0.62 , respectively). For cell production features $\mathrm{N}$ and $\mathrm{TRW}$, no high correlations are detected between local chronologies of different altitudes.

The relationships between different tree ring features have the same patterns regardless of elevation (Fig. 4, Table 3). For each site, cell number have positive correlations with maximal and particularly mean radial diameters (0.22-0.47 and 0.34-0.53 for Dmax and Dmean, respectively), and TRW have similar but higher correlations with cell size (0.33-0.62 and $0.50-0.72$, respectively). A highly negative relationship is observed between maximal cell wall thickness and relative position of the transition to latewood (correlations from - 0.76 to 0.58). In regard to the interrelations between anatomical proxies of wall deposition and other tree ring features, significant correlations are observed only at the MID site and are weaker than most of the others (correlations from -0.35 to -0.16 for Pos and $0.39-0.58$ for CWTmax).

Dendroclimatic correlation analysis revealed periods when temperature and precipitation have the most significant effects on the considered tree ring features in accordance with the site location along the altitudinal gradient and the corresponding gradients in temperature and growth season duration (Fig. 5). Cell production and indices of TRW responses to climatic variation are weak, although the tendency of a positive temperature effect and a negative precipitation influence at the upper tree line is noted, as well as reverse patterns at the lower spruce range boundary. Anatomical traits have a more pronounced climatic response. For the maximal and mean cell radial diameters at the HIGH area, a significant positive effect of the temperature during the first half of June is observed; at MID and LOW sites, a negative effect of temperature and a positive effect of precipitation are observed from late May to mid-June.

The position of the transition to thick-walled cells has a positive relationship with the temperature of mid-June at the HIGH and MID sites. However, at the LOW site, this reaction is replaced by a negative one and shifted to the beginning of the month, but precipitation affects this anatomical trait positively in the second half of June. The maximal cell wall thickness at all elevations responds positively to temperature at the end of the growth season: mid-August at the upper tree line, the second half of August in the centre of the range, and early September at the lower limit of spruce growth. This significant response notably coincides with the approximate date of the temperature decrease below the $+10^{\circ} \mathrm{C}$ threshold at all elevations.

\section{Discussion}


Tree ring width is an integral parameter that is the sum of radial diameters for the total $\mathrm{N}$ cells produced during the season. Because the average radial cell diameter during a tree life span does not have strong age-related changes or show other significant long-term trends (Vysotskaya and Vaganov, 1989; Lei et al., 1996; Vaganov et al., 2006; Eilmann et al., 2009; Hughes et al., 2010; Zeng et al., 2017), the relationship between radial growth and cell production is almost linear. Relative stability of this dependence within a site and to some extent on a larger scale was observed for Siberian spruce in comparison with other conifer species of the region. This finding is consistent with the low sensitivity (year-to-year variability) of radial growth noted for some Picea spp. even in severe environments (Mäkinen et al., 2002; Savva et al., 2006; Babushkina et al., 2011; Sidor et al., 2015; Jiao et al., 2016; Lei et al., 2016), i.e. typical for spruce with a low degree of secondary growth plasticity. However, a positive relationship between the maximal tracheid production (and maximal TRW) and their size is notable. A possible reason for such a relationship may be the dependence of the final radial cell diameter on the rate of their production by the cambial zone, which is indirectly included in the Vaganov-Shashkin simulation model of tree growth (Fritts et al., 1991; Vaganov et al., 2006; Shishov et al., 2016; Deslauriers et al., 2017; Li et al., 2017). Actually, the combination of modelling and anatomical measurements of tree rings is very promising, as recently shown in several publications (Drew and Downes, 2015; Hartmann et al., 2017; Kulmala et al., 2017; Arzac et al., 2018). Mean and maximal radial cell diameters have higher correlations with TRW than with cell production, because TRW a priori integrates the common signal not only from the production process but also to a lesser degree from cell expansion, thereby forming an additional causal link.

After transition from the cell expansion process to cell wall deposition, the previously observed close positive relationships between the resulting anatomical traits decline sharply, i.e. this stage of tracheid differentiation depends on the preceding processes only to a small extent and contains primarily its independent signal on the external conditions (Larson, 1994). This assumption is indirectly confirmed by the higher variation and lower autocorrelation of the features associated with cell wall thickening, compared with other tree ring traits. Additionally, maximal wood density, which is closely related to the cell wall thickness in latewood (Björklund et al., 2017), often has a climatic response different from that of TRW (Briffa et al., 2002; Kirdyanov et al., 2007; Sun et al., 2016; Rathgeber, 2017; Stine and Huybers, 2017), which also supports our assumption. Nevertheless, within the tree ring, interrelations of cell wall thickness with cell number and their diameters are complex and 
nonlinear (see examples in Vaganov et al., 1985; Babushkina et al., 2010; Silkin, 2010; Sviderskaya et al., 2011; Luostarinen, 2012).

The stable negative correlation between relative position of the transition to latewood and the maximal cell wall thickness is of interest not only anatomically but also physiologically. The earlier such a transition (a noticeable thickening of the cell wall) is observed in the ring, the larger the maximal thickness the cell wall can reach in the mid of latewood. Moreover, for the data presented, Pos and CWTmax do not show any close connections with the radial size of the tracheids either in time (considering different years) or along the altitudinal gradient. External and internal triggers for the development of thickwalled tracheids have been and remain the subject of discussion since the 1970s. Depending on the regional conditions, researchers suggest sharp temperature declines, late summer droughts, and a noticeable decrease in the insolation (photoperiod) as such triggers (Wareing and Phillips, 1970; Wodzicki et al., 1971; Heide, 1974; Denne, 1976; Jenkins et al., 1977). Based on the results of the dendroclimatic analysis (Fig. 5), in accordance with the growthlimiting role of temperature and moisture supply at the upper and lower boundaries of the spruce range, respectively, these factors have a significant effect on the transition to thickwalled cells at the same time at all elevations, in the second half of June (near the summer solstice). Although all three aforementioned external factors are involved in switching biosynthetic processes in the cells of the emerging xylem, the incoming solar radiation seems to be main trigger. This finding can be connected with the end of seasonal growth of shoots and photosynthetic apparatus (Vaganov and Terskov, 1977). In particular, Cooke et al. (2012) noted that bud set for spruce occurs under the combined effect of photoperiod and intrinsic control, and Rossi et al. (2009) observed the transition to the wall thickening of the first latewood cells at the moment of primary growth cessation in several conifers. Therefore, we should also expect hormonal and genetic control of the switching of xylem differentiation processes to the latewood development (Hartmann et al., 2017).

A joint analysis of the values of tree ring features and the relationships between their chronologies along the altitudinal gradient (Fig. 6) showed that the chronologies of the same feature closely correlate in the same part of the spruce range for which the dependence of their values on the ecological gradient is present. However, once these values reach a certain limit, they cease to change further because of certain genetic, physiological or anatomical restriction, which leads to a weakening or complete absence of significant correlations. For example, in the lower half of the range (LOW-MID), the mean and maximum radial cell diameters decrease with elevation, most likely in concert with the temperature-related general 
growth rate of trees (Vaganov et al., 2006; Castagneri et al., 2017; Deslauriers et al., 2017). However, comparison of HIGH and MID sites showed the same range of tracheid radial sizes and no correlations between their chronologies, which could be due to the physiological requirements for minimum hydraulic conductivity of earlywood tracheids and in general due to species-specific genetic requirements for the wood structure. These requirements were observed, for example, in a comparison of heterodrafts wood anatomy with Pinus sibirica scions and Pinus sylvestris rootstocks, which minimized differences in external influences and hormonal control, thereby highlighting species-specific genetics (Darikova et al., 2013).

For cell wall thickening result, the elevational pattern is reversed: in the high part of spruce range (MID-HIGH), a decrease in CWTmax and latewood proportion with elevation is evident and high correlations between local chronologies of the same trait. With earlier onset and later end of the vegetative season, the duration for cell production and differentiation processes, including cell wall deposition, is longer at the lower elevation (Gindl et al., 2000, 2001; Rossi et al., 2012). At the same time, these relationships are absent when comparing LOW and MID sites. This finding can be related to one or a combination of reasons: obvious anatomical restriction of $\mathrm{CWT}<\mathrm{D} / 2$ in latewood, limitation of cell wall deposition by mineral resource availability in soil (in the study area, fertility is usually not high), and the aforementioned genetic predispositions in wood anatomy. Another possible reason for the complicated elevational patterns in tree ring features is a shift of growth-regulating (limiting) factors from moisture to heat supply with altitude; however, this assumption is easily verified by analysing the climatic response.

Unlike cell production (and radial increment), the other anatomical traits have more consistent temporal patterns in climatic responses along the altitudinal gradient. For the maximal cell size, the conditions of the same period (the first half of June) are important regardless of elevation, although the direction of the climatic reactions varies. Given that the cell size usually reaches a maximum in the second half of earlywood, i.e. shortly before the transition to latewood, this can serve as an indirect confirmation of the regulation the transition to narrower cells by day length. However, we may also propose mechanical connections between the maxima in the photoperiod and in the radial diameters of emerging cells in terms of the general rate of the tree secondary growth (i.e. both rates of cell division and expansion changing consistently with day length). The argument in favour of this assumption is based on observations of the maximum rates of radial growth and wood cell production in conifers during the summer solstice (Rossi et al., 2006a; Gruber et al., 2009). 
By contrast, the reaction of CWTmax to the end-of-season temperature is positive regardless of elevation, because during this period, the completed foliage formation predetermines the stable production of photoassimilates for cell wall deposition at all altitudes, and moisture supply is sufficient even at the lower boundary of the spruce range. Evidence indicates that the decrease in temperature limits primarily the process of organic substances deposition in the structure of the plant (Cavieres et al., 2000; Hoch et al., 2002; Hoch and Körner, 2003; Körner and Paulsen, 2004; Piper et al., 2006; Alvarez-Uria and Körner, 2007; Rossi et al., 2008), leading to a suppression of the cell wall thickening before the photosynthesis processes begin to suffer. However, the timing of CWTmax climatic response has an explicit gradient, and at all altitudes, the maximum occurs on the approximate date of the temperature transition under the threshold of $+10^{\circ} \mathrm{C}$. As it was shown in previous study for $+5^{\circ} \mathrm{C}$ threshold (Babushkina et al., 2018), long-term trend of the end of season date is relatively low in the study area. Its 3-day shift due to warming can be disregarded here in comparison with window of dendroclimatic analysis. Several studies show that the rate of transition processes from primary growth cessation to full plant dormancy is also regulated by temperature (Cooke et al., 2012), and that plants also tend to become dormant at a temperature of c. $8-10^{\circ} \mathrm{C}$ (Kramer and Kozlowski, 1979; Rossi et al., 2008). Therefore, this finding supports the hypothesis on the specific effect of the timing of the end of the growth season on the process of cell wall thickening in latewood tracheids.

\section{Conclusions}

All the considered anatomical traits are under the influence of climatic factors throughout the entire altitudinal range of the spruce distribution, and the direction of this influence is only partially elevation-dependent. Therefore, observed patterns in values and inter-elevational correlations of tree ring features are determined by the combination of change of the limiting factor with elevation and internal restriction of wood anatomical structure.

Analysis of climatic signals in tracheid anatomical traits obviously requires special tools with a fine temporal resolution. At this stage, we can state that such a tool is the application of moving climatic series with the selected window and step. Considering these results more broadly, namely, for expected climate changes, the high temporal resolution obtained from wood anatomy is essential in analysing the tree growth-climate relationships in future, particularly with regard to the increasing frequency of extreme climatic events at different times during the growth season. 


\section{Acknowledgements}

The authors would like to thank the administration of the National Park 'Shushensky Bor' and personally its director Tolmachev V.A. for providing permission and facilitating fieldwork in the park territory. The research reported in this manuscript was supported by the Russian Foundation for Basic Research (grant numbers 17-04-00315, 17-44-240809). 


\section{References}

Alvarez-Uria, P., Körner, C., 2007. Low temperature limits of root growth in deciduous and evergreen temperate tree species. Funct. Ecol. 21, 211-218. https://doi.org/10.1111/j.1365-2435.2007.01231.x.

Anfodillo, T., Deslauriers, A., Menardi, R., Tedoldi, L., Petit, G., Rossi, S., 2012. Widening of xylem conduits in a conifer tree depends on the longer time of cell expansion downwards along the stem. J. Exp. Bot. 63, 837-845. https://doi.org/10.1093/jxb/err309.

Antonova, G.F., Stasova, V.V., 1997. Effects of environmental factors on wood formation in larch (Larix sibirica Ldb.) stems. Trees 11(8), 462-468. https://doi.org/10.1007/PL00009687.

von Arx, G., Carrer, M., 2014. ROXAS - A new tool to build centuries-long tracheidlumen chronologies in conifers. Dendrochronologia 32(3), 290-293. https://doi.org/10.1016/j.dendro.2013.12.001.

von Arx, G., Crivellaro, A., Prendin, A.L., Čufar, K., Carrer, M., 2016. Quantitative wood anatomy - practical guidelines. Front. Plant Sci. 7, 781. https://doi.org/10.3389/fpls.2016.00781.

von Arx, G., Carrer, M., Björklund, J., Fonti, P., 2018. Quantitative wood anatomy opens a weekly to millennial time window in tree-ring research. In: Geophysical Research Abstracts, Vol. 20, EGU2018. 18929 p.

Arzac, A., Babushkina, E.A., Fonti, P., Slobodchikova, V., Sviderskaya, I.V., Vaganov, E.A., 2018. Evidences of wider latewood in Pinus sylvestris from a forest-steppe of Southern Siberia. Dendrochronologia 49, 1-8. https://doi.org/10.1016/j.dendro.2018.02.007.

Asante, D.K., Yakovlev, I.A., Fossdal, C.G., Holefors, A., Opseth, L., Olsen, J.E., Junttila, O., Johnsen, Ø., 2011. Gene expression changes during short day induced terminal bud formation in Norway spruce. Plant Cell Environ. 34(2), 332-346. https://doi.org/10.1111/j.1365-3040.2010.02247.x.

Babushkina, E.A., Vaganov, E.A., Silkin, P.P., 2010. Effect of climatic factors on the cellular structure of tree rings in conifers growing under different topoecological conditions in the forest steppe zone of Khakassia. J. Sib. Fed. Univ. Biol. 2(3), 159-176 (in Russian).

Babushkina, E.A., Knorre, A.A., Vaganov, E.A., Bryukhanova, M.V., 2011. Transformation of climatic response in radial increment of trees depending on topoecological conditions of their occurrence. Geogr. Nat. Res. 32(1), 80-86. https://doi.org/10.1134/S1875372811010148. 
Babushkina, E.A., Belokopytova, L.V., Kostyakova, T.V., Kokova, V.I., 2018a. Earlywood and latewood features of Pinus sylvestris in semiarid natural zones of South Siberia. Russ. J. Ecol. 3, 174-183. https://doi.org/10.1134/S1067413618030013.

Babushkina E., Belokopytova L., Zhirnova D., Barabantsova A., Vaganov E., 2018. Divergent growth trends and climatic response of Picea obovata along elevational gradient in Western Sayan mountains, Siberia. J Mount Sci. 15(11), 2378-2397. https://doi.org/10.1007/s11629-018-4974-6.

Balducci, L., Cuny, H., Rathgeber, C., Deslauriers, A., Giovannelli, A., Rossi, S., 2016. Compensatory mechanisms mitigate the effect of warming and drought on wood formation. Plant Cell Environ. 39(6), 1338-1352. https://doi.org/10.1111/pce.12689.

Belokopytova, L.V., Babushkina, E.A., Zhirnova, D.F., Panyushkina, I.P., Vaganov, E.A., 2018a. Climatic response of conifer radial growth in forest-steppes of South Siberia: comparison of three approaches. Contemp. Probl. Ecol. 11(4), 366-376. https://doi.org/10.1134/S1995425518040030.

Belokopytova, L.V., Babushkina, E.A., Zhirnova, D.F., Panyushkina, I.P., Vaganov, E.A., 2018b. Pine and larch tracheids capture seasonal variations of climatic signal at moisture-limited sites. Trees. https://doi.org/10.1007/s00468-018-1772-2

Björklund, J., Seftigen, K., Schweingruber, F., Fonti, P., von Arx, G., Bryukhanova, M.V., Cuny, H.E., Carrer, M., Castagneri, D., Frank, D.C., 2017. Cell size and wall dimensions drive distinct variability of earlywood and latewood density in Northern Hemisphere conifers. New Phytol. 216(3), 728-740. https://doi.org/10.1111/nph.14639.

Bowyer, J., Shmulsky, R., Haygreen, J.G., 2003. Forest products and wood science: an introduction. Iowa State Press, Ames, 554 pp.

Briffa, K.R., Osborn, T.J., Schweingruber, F.H., Jones, P.D., Shiyatov, S.G., Vaganov, E.A., 2002. Tree-ring width and density data around the Northern Hemisphere: Part 1, local and regional climate signals. Holocene 12(6), 737-757. https://doi.org/10.1191/0959683602h1587rp

Brown, H.P., Panshin, A.J., Forsaith, C.C., 1949. Textbook of wood technology. Vol. 1. Structure, identification, defects and uses of the commercial woods of the United States. McGraw-Hill, New York, 652 pp.

Camarero, J.J., Olano, J.M., Parras, A., 2010. Plastic bimodal xylogenesis in conifers from continental Mediterranean climates. New Phytol. 185(2), 471-480. https://doi.org/10.1111/j.1469-8137.2009.03073.x. 
Carrer, M., Castagneri, D., Prendin, A.L., Petit, G., von Arx, G., 2017. Retrospective analysis of wood anatomical traits reveals a recent extension in tree cambial activity in two high-elevation conifers. Front. Plant Sci. 8, 737. https://doi.org/10.3389/fpls.2017.00737.

Castagneri, D., Fonti, P., von Arx, G., Carrer, M., 2017. How does climate influence xylem morphogenesis over the growing season? Insights from long-term intra-ring anatomy in Picea abies. Ann. Bot. 119(6), 1011-1020. https://doi.org/10.1093/aob/mcw274.

Cato, S., McMillan, L., Donaldson, L., Richardson, T., Echt, C., Gardner, R., 2006. Wood formation from the base to the crown in Pinus radiata: gradients of tracheid wall thickness, wood density, radial growth rate and gene expression. Plant Mol. Biol. 60(4), 565581. https://doi.org/10.1007/s11103-005-5022-9.

Cavieres, L.A., Rada, F., Azócar, A., García-Núnez, C., Cabrera, H.M., 2000. Gas exchange and low temperature resistance in two tropical high mountain tree species from the Venezuelan Andes. Acta Oecologica 21(3), 203-211. https://doi.org/10.1016/S1146609X(00)01077-8.

Cook, E.R., Kairiukstis, L.A. (Eds.), 1990. Methods of Dendrochronology. Application in Environmental Sciences. Springer Netherlands, Dordrecht, 394 pp. https://doi.org/10.1007/978-94-015-7879-0.

Cook, E.R., Krusic, P.J., 2005. Program ARSTAN. A tree-ring standardization program based on detrending and autoregressive time series modeling, with interactive graphics. http://www.ldeo.columbia.edu/sites/default/files/res/fac/trl/downloads/software/AR STAN_XP.zip [accessed 2 April 2018].

Cooke, J.E., Eriksson, M.E., Junttila, O., 2012. The dynamic nature of bud dormancy in trees: environmental control and molecular mechanisms. Plant Cell Environ. 35(10), 17071728. https://doi.org/10.1111/j.1365-3040.2012.02552.x.

Cuny, H., 2013. Intra-annual wood formation dynamics of three conifer species (silver fir, Norway spruce, and Scots pine) in northeast France: From the description of the growth seasonal patterns to the study of the environmental influence on the kinetics of cell development and the anatomical features of the xylem. Dissertation, University of Lorraine, Nancy, France (in Franch).

Cuny, H.E., Rathgeber, C.B., Kiessé, T.S., Hartmann, F.P., Barbeito, I., Fournier, M., 2013. Generalized additive models reveal the intrinsic complexity of wood formation dynamics. J. Exp. Bot. 64(7), 1983-1994. https://doi.org/10.1093/jxb/ert057. 
Cuny, H.E., Rathgeber, C.B., Frank, D., Fonti, P., Fournier, M., 2014. Kinetics of tracheid development explains conifer tree-ring structure. New Phytol. 203(4), 1231-1241. https://doi.org/10.1111/nph.12871.

Darikova, Y.A., Vaganov, E.A., Kuznetsova, G.V., Grachev, A.M., 2013. Changes in the anatomical structure of tree rings of the rootstock and scion in the heterografts of Siberian pine. Trees 27(6), 1621-1631. https://doi.org/10.1007/s00468-013-0909-6.

Denne, M.P., 1972. A comparison of root-and shoot-wood development in conifer seedlings. Ann. Bot. 36(3), 579-587.

Denne, M.P., 1976. Effects of environmental change on wood production and wood structure in Picea sitchensis seedlings. Ann. Bot. 40(5), 1017-1028. https://doi.org/10.1093/oxfordjournals.aob.a085209.

Denne, M.P., 1989. Definition of latewood according to Mork (1928). IAWA J. 10, $59-62$.

Deslauriers, A., Fonti, P., Rossi, S., Rathgeber, C.B.K., Gričar, J., 2017. Ecophysiology and plasticity of wood and phloem formation, in: Amoroso, M., Daniels, L., Baker, P., Camarero, J. (Eds.), Dendroecology. Ecological Studies (Analysis and Synthesis). Springer, Cham, pp. 13-33.

Dodd, R.S., Fox, P., 1990. Kinetics of tracheid differentiation in Douglas-fir. Ann. Bot. 65(6), 649-657. https://doi.org/10.1093/oxfordjournals.aob.a087983.

Drew, D.M., Downes, G., 2015. A model of stem growth and wood formation in Pinus radiata. Trees 29(5), 1395-1413. https://doi.org/10.1007/s00468-015-1216-1.

Eilmann, B., Zweifel, R., Buchmann, N., Fonti, P., Rigling, A., 2009. Droughtinduced adaptation of the xylem in Scots pine and pubescent oak. Tree Phys. 29(8), 10111020. https://doi.org/10.1093/treephys/tpp035.

Fritts, H.C., Vaganov, E.A., Sviderskaya, I.V., Shashkin, A.V., 1991. Climatic variation and tree-ring structure in conifers: empirical and mechanistic models of tree-ring width, number of cell, cell size, cell-wall thickness and wood density. Clim. Res. 1, 97-116. https://doi.org/10.3354/cr001097.

Gartner, B.L., 1995. Patterns of xylem variation within a tree and their hydraulic and mechanical consequences, in: Gartner, B. (Ed.), Plant stems: physiological morphology. Academic Press, New York, pp. 125-149.

Gärtner, H., Cherubini, P., Fonti, P., von Arx, G., Schneider, L., Nievergelt, D., Verstege, A., Bast, A., Schweingruber, F.H., Büntgen, U., 2015. A technical perspective in 
modern tree-ring research - how to overcome dendroecological and wood anatomical challenges. J. Vis. Exp. 97, e52337. https://doi.org/10.3791/52337.

Gindl, W., Grabner, M., Wimmer, R., 2000. The influence of temperature on latewood lignin content in treeline Norway spruce compared with maximum density and ring width. Trees 14, 409-414. https://doi.org/10.1007/s004680000057.

Gindl, W., Grabner, M., Wimmer, R., 2001. Effects of altitude on tracheid differentiation and lignification of Norway spruce. Can. J. Bot. 79, 815-821. https://doi.org/10.1139/b01-060.

Gruber, A., Baumgartner, D., Zimmermann, J., Oberhuber, W., 2009. Temporal dynamic of wood formation in Pinus cembra along the alpine treeline ecotone and the effect of climate variables. Trees 23, 623-635. https://doi.org/10.1007/s00468-008-0307-7.

Gyllenstrand, N., Clapham, D., Källman, T., Lagercrantz, U., 2007. A Norway spruce FLOWERING LOCUS T homolog is implicated in control of growth rhythm in conifers. Plant Physiol. 144(1), 248-257. https://doi.org/10.1104/pp.107.095802.

Hannrup, B., 2001. Relationships between wood density and tracheid dimensions in Pinus sylvestris L. Wood Fiber Sci. 31(2), 173-181.

Hansen, J., Türk, R., Vogg, G., Heim, R., Beck, E., 1997. Conifer carbohydrate physiology: updating classical views, in: Rennenberg, H., Eschrich, W., Ziegler, H. (Eds.), Trees: contributions to modern tree physiology. Backhuys Publishers, Leiden, pp. 97-108.

Hartmann, F.P., Rathgeber, C.B.K., Fournier, M., Moulia, B., 2017. Modelling wood formation and structure: power and limits of a morphogenetic gradient in controlling xylem cell proliferation and growth. Ann. For. Sci. 74, 14. https://doi.org/10.1007/s13595-016-0613y.

Heide, O.M., 1974. Growth and dormancy in Norway spruce ecotypes (Picea abies) I. Interaction of photoperiod and temperature. Physiol. Plant. 30(1), 1-12. https://doi.org/10.1111/j.1399-3054.1974.tb04983.x.

Helama, S., Sutinen, R., 2016. Inter- and intra-seasonal effects of temperature variation on radial growth of alpine treeline Norway spruce. J. Mt. Sci. 13(1), 1-12. https://doi.org/10.1007/s11629-015-3665-9.

Hoch, G., Popp, M., Körner, C., 2002. Altitudinal increase of mobile carbon pools in Pinus cembra suggests sink limitation of growth at the Swiss treeline. Oikos 98, 361-374. https://doi.org/10.1034/j.1600-0706.2002.980301.x.

Hoch, G., Körner, C., 2003. The carbon charging of pines at the climatic treeline: a global comparison. Oecologia 135(1), 10-21. https://doi.org/10.1007/s00442-002-1154-7. 
Holmes, R.L., 1983. Computer-assisted quality control in tree-ring dating and measurement. Tree-Ring Bull. 43, 68-78.

Hölttä, T., Mäkinen, H., Nöjd, P., Mäkelä, A., Nikinmaa, E., 2010. A physiological model of softwood cambial growth. Tree Physiol. 30, 1235-1252. https://doi.org/10.1093/treephys/tpq068.

Horacek, P., Slezingerova, J., Gandelova, L., 1999. Effects of environment on the xylogenesis of Norway spruce (Picea abies L. Karst.), in: Wimmer, R., Vetter, R.E. (Eds.), Tree-ring analysis: biological, methodological and environmental aspects. CABI Publishing, Wallingford, pp. 33-53.

Hughes, M.K., Swetnam, T.W., Diaz, H.F. (Eds.), 2010. Dendroclimatology: Progress and Prospects. Springer, Heidelberg, 368 pp.

Jenkins, P.A., Hellmers, H., Edge, E.A., Rook, D.A., Burdon, R.D., 1977. Influence of photoperiod on growth and wood formation of Pinus radiata. N.Z. J. For. Sci. 7(2), 172-191.

Jiao, L., Jiang, Y., Wang, M., Kang, X., Zhang, W., Zhang, L., Zhao, S., 2016. Responses to climate change in radial growth of Picea schrenkiana along elevations of the eastern Tianshan Mountains, northwest China. Dendrochronologia 40, 117-127. https://doi.org/10.1016/j.dendro.2016.09.002.

Jyske, T., Mäkinen, H., Kalliokoski, T., Nöjd, P., 2014. Intra-annual tracheid production of Norway spruce and Scots pine across a latitudinal gradient in Finland. Agric. For. Meteorol. 194, 241-254. https://doi.org/10.1016/j.agrformet.2014.04.015.

Karlgren, A., Gyllenstrand, N., Clapham, D., Lagercrantz, U., 2013. FLOWERING LOCUS T/TERMINAL FLOWER1-like genes affect growth rhythm and bud set in Norway spruce. Plant Physiol. 163(2), 792-803. https://doi.org/10.1104/pp.113.224139.

Kirdyanov, A.V., Vaganov, E.A., Hughes, M.K., 2007. Separating the climatic signal from tree-ring width and maximum latewood density records. Trees 21(1), 37-44. https://doi.org/10.1007/s00468-006-0094-y.

Körner, C., Paulsen, J., 2004. A world-wide study of high altitude treeline temperatures. J. Biogeogr. 31, 713-732. https://doi.org/10.1111/j.1365-2699.2003.01043.x.

Kramer, P.J., Kozlowski, T.T., 1979. Physiology of woody plants. Academic Press, New York, 811 pp.

Kraus, C., Zang, C., Menzel, A., 2016. Elevational response in leaf and xylem phenology reveals different prolongation of growing period of common beech and Norway spruce under warming conditions in the Bavarian Alps. Eur. J. For. Res. 135, 1011-1023. https://doi.org/10.1007/s10342-016-0990-7. 
Kulmala, L., Read, J., Nöjd, P., Rathgeber, C.B., Cuny, H.E., Hollmén, J., Mäkinen, H., 2017. Identifying the main drivers for the production and maturation of Scots pine tracheids along a temperature gradient. Agric. For. Meteorol. 232, 210-224. https://doi.org/10.1016/j.agrformet.2016.08.012.

Larson, P.R., 1994. The vascular cambium. Development and structure. SpringerVerlag, Berlin; Heidelberg, 725 p.

Lei, H., Milota, M.R., Gartner, B.L., 1996. Between- and within-tree variation in the anatomy and specific gravity of wood in Oregon white oak (Quercus garryana Dougl.). IAWA J. 17, 445-461. https://doi.org/10.1163/22941932-90000642.

Lei, J.P., Feng, X.H., Shi, Z., Bai, D.Z., Xiao, W.F., 2016. Climate-growth relationship stability of Picea crassifolia on an elevation gradient, Qilian Mountain, Northwest China. J. Mt. Sci. 13(4), 734-743. https://doi.org/10.1007/s11629-015-3784-3.

Li, X., Liang, E., Gričar, J., Prislan, P., Rossi, S., Čufar, K., 2012. Age dependence of xylogenesis and its climatic sensitivity in Smith fir on the south-eastern Tibetan Plateau. Tree Physiol. 33(1), 48-56. https://doi.org/10.1093/treephys/tps113.

Li, X., Liang, E., Gričar, J., Rossi, S., Čufar, K., Ellison, A.M., 2017. Critical minimum temperature limits xylogenesis and maintains treelines on the southeastern Tibetan Plateau. Sci. Bull. 62(11), 804-812. https://doi.org/10.1016/j.scib.2017.04.025.

Lindström, H., 1997. Fiber length, tracheid diameter, and latewood percentage in Norway spruce: development from pith outward. Wood Fiber Sci. 29(1), 21-34.

Luostarinen, K., 2012. Tracheid wall thickness and lumen diameter in different axial and radial locations in cultivated Larix sibirica trunks. Silva Fenn. 46(5), 707-716. https://doi.org/10.14214/sf.921.

Lupi, C., Morin, H., Deslauriers, A., Rossi, S., 2010. Xylem phenology and wood production: resolving the chicken-or-egg dilemma. Plant Cell Environ. 33(10), 1721-1730. https://doi.org/10.1111/j.1365-3040.2010.02176.x.

Mäkinen, H., Nöjd, P., Kahle, H.P., Neumann, U., Tveite, B., Mielikäinen, K., Röhle, H., Spiecker, H., 2002. Radial growth variation of Norway spruce (Picea abies (L.) Karst.) across latitudinal and altitudinal gradients in central and northern Europe. Forest Ecol. Manag. 171(3), 243-259. https://doi.org/10.1016/S0378-1127(01)00786-1.

Mäkinen, H., Jyske, T., Nöjd, P., 2018. Dynamics of diameter and height increment of Norway spruce and Scots pine in southern Finland. Ann. For. Sci. 75, 28. https://doi.org/10.1007/s13595-018-0710-1. 
Moehring, D.M., Grano, C.X., Bassett, J.R., 1975. Xylem development of loblolly pine during irrigation and simulated drought. U.S. Department of Agriculture, Forest Service, Southern Forest Experiment Station, Research Paper SO-I 10, New Orleans, 8 pp.

Mork, E., 1928. Die Qualitat des Fichtenhozes unter besonder Rucksichtnahme auf Schleif und Papierholz. Papier Fabr. 26, 741-747 (in German).

Myglan, V.S., 2010. The climate and society of Siberia in the small ice age. Siberian Federal University, Krasnoyarsk, 230 pp. (in Russian)

Olano, J.M., Linares, J.C., García-Cervigón, A.I., Arzac, A., Delgado, A., Rozas, V., 2014. Drought-induced increase in water-use efficiency reduces secondary tree growth and tracheid wall thickness in a Mediterranean conifer. Oecologia 176(1), 273-283. https://doi.org/10.1007/s00442-014-2989-4.

Peters, R.L., Balanzategui, D., Hurley, A.G., von Arx, G., Prendin, A.L., Cuny, H.E., Björklund, J., Frank, D.C., Fonti, P., 2018. RAPTOR: Row and position tracheid organizer in R. Dendrochronologia 47, 10-16. https://doi.org/10.1016/j.dendro.2017.10.003.

Petit, G., Crivellaro, A., 2014. Comparative axial widening of phloem and xylem conduits in small woody plants. Trees 28, 915-921. https://doi.org/10.1007/s00468-014-10061.

Petterle, A., Karlberg, A., Bhalerao, R.P., 2013. Daylength mediated control of seasonal growth patterns in perennial trees. Curr. Opin. Plant Biol. 16(3), 301-306. https://doi.org/10.1016/j.pbi.2013.02.006.

Piper, F.I., Cavieres, L.A., Reyes-Díaz, M., Corcuera, L.J., 2006. Carbon sink limitation and frost tolerance control performance on the tree Kageneckia angustifolia D. Don (Rosaceae) at the treeline in central Chile. Plant Ecol. 185, 29-39. https://doi.org/10.1007/s11258-005-9081-4.

Plomion, C., Leprovost, G., Stokes, A., 2001. Wood formation in trees. Plant Physiol. 127, 1513-1523. https://doi.org/10.1104/pp.010816.

Prendin, A.L., Petit, G., Carrer, M., Fonti, P., Björklund, J., von Arx, G., 2017. New research perspectives from a novel approach to quantify tracheid wall thickness. Tree Physiol. 37(7), 976-983. https://doi.org/10.1093/treephys/tpx037.

Rathgeber, C.B., 2017. Conifer tree-ring density inter-annual variability - anatomical, physiological and environmental determinants. New Phytol. 216(3), 621-625. https://doi.org/10.1111/nph.14763.

Rinn, F., 2003. TSAP-Win: Time series analysis and presentation for dendrochronology and related applications: User reference. RINNTECH, Heidelberg, 91 pp. 
Rossi, S., Deslauriers, A., Anfodillo, T., Morin, H., Saracino, A., Motta, R., Borghetti, M., 2006a. Conifers in cold environments synchronize maximum growth rate of tree-ring formation with day length. New Phytol. 170(2), 301-310. https://doi.org/10.1111/j.14698137.2006.01660.x.

Rossi, S., Deslauriers, A., Anfodillo, T., 2006b. Assessment of cambial activity and xylogenesis by microsampling tree species: an example at the Alpine timberline. IAWA J. 27, 383-394. https://doi.org/10.1163/22941932-90000161.

Rossi, S., Deslauriers, A., Anfodillo, T., Carraro, V., 2007. Evidence of threshold temperatures for xylogenesis in conifers at high altitudes. Oecologia 152(1), 1-12. https://doi.org/10.1007/s00442-006-0625-7.

Rossi, S., Deslauriers, A., Griçar, J., Seo, J.W., Rathgeber, C.B., Anfodillo, T., Morin, H., Levanic, T., Oven, P., Jalkanen, R., 2008. Critical temperatures for xylogenesis in conifers of cold climates. Glob. Ecol. Biogeogr. 17(6), 696-707. https://doi.org/10.1111/j.14668238.2008.00417.x.

Rossi, S., Rathgeber, C.B.K., Deslauriers, A., 2009. Comparing needle and shoot phenology with xylem development on three conifer species in Italy. Ann. For. Sci. 66(2), 206. https://doi.org/10.1051/forest/2008088.

Rossi, S., Morin, H., Deslauriers, A., Plourde, P.-Y., 2011. Predicting xylem phenology in black spruce under climate warming. Glob. Change Biol. 17, 614-625. https://doi.org/10.1111/j.1365-2486.2010.02191.x.

Rossi, D., Rossi, S., Morin, H., Bettero, A., 2012. Within-tree variations in the surface free energy of wood assessed by contact angle analysis. Wood Sci. Technol. 46, 287-298. https://doi.org/10.1007/s00226-011-0407-1.

Rozenberg, P., Franc, A., Mamdy, C., Launay, J., Schermann, N., Bastien, J.C., 1999. Genetic control of stiffness of standing Douglas fir; from the standing stem to the standardised wood sample, relationships between modulus of elasticity and wood density parameters. Part II. Ann. For. Sci. 56(2), 145-154. https://doi.org/10.1051/forest:19990206.

Russo, S.E., Jenkins, K.L., Wiser, S.K., Uriarte, M., Duncan, R.P., Coomes, D.A., 2010. Interspecific relationships among growth, mortality and xylem traits of woody species from New Zealand. Funct. Ecol. 24(2), 253-262. https://doi.org/10.1111/j.13652435.2009.01670.x.

Savva, Y., Oleksyn, J., Reich, P.B., Tjoelker, M.G., Vaganov, E.A., Modrzynski, J., 2006. Interannual growth response of Norway spruce to climate along an altitudinal gradient 
in the Tatra Mountains, Poland. Trees 20(6), 735-746. https://doi.org/10.1007/s00468-0060088-9.

Schweingruber, F.H., 1990. Microscopic wood anatomy: structural variability of stems and twigs in recent and subfossil woods from Central Europe. WSL, Birmensdorf, 226 pp.

Schrader, J., Baba, K., May, S.T., Palme, K., Bennett, M., Bhalerao, R.P., Sandberg, G., 2003. Polar auxin transport in the wood-forming tissues of hybrid aspen is under simultaneous control of developmental and environmental signals. PNAS 100(17), 1009610101. https://doi.org/10.1073/pnas.1633693100.

Schrader, J., Nilsson, J., Mellerowicz, E., Berglund, A., Nilsson, P., Hertzberg, M., Sandberg, G., 2004. A high-resolution transcript profile across the wood-forming meristem of poplar identifies potential regulators of cambial stem cell identity. Plant Cell 16(9), 22782292. https://dx.doi.org/10.1105/tpc.104.024190.

Seo, J.W., Smiljanić, M., Wilmking, M., 2014. Optimizing cell-anatomical chronologies of Scots pine by stepwise increasing the number of radial tracheid rows included - Case study based on three Scandinavian sites. Dendrochronologia 32(3), 205-209. https://doi.org/10.1016/j.dendro.2014.02.002.

Shishov, V.V., Tychkov, I.I., Popkova, M.I., Ilyin, V.A., Bryukhanova, M.V., Kirdyanov, A.V., 2016. VS-oscilloscope: A new tool to parameterize tree radial growth based on climate conditions. Dendrochronologia 42-50. http://dx.doi.org/10.1016/j.dendro.2015.10.001.

Sidor, C.G., Popa, I., Vlad, R., Cherubini, P., 2015. Different tree-ring responses of Norway spruce to air temperature across an altitudinal gradient in the Eastern Carpathians (Romania). Trees 29(4), 985-997. https://doi.org/10.1007/s00468-015-1178-3.

Silkin, P.P., 2010. Methods of multiparameter analysis of conifers tree-rings structure. Siberian Federal University, Krasnoyarsk, 335 pp. (in Russian).

Simard, S., Giovannelli, A., Treydte, K., Traversi, M.L., King, G.M., Frank, D., Fonti, P., 2013. Intra-annual dynamics of non-structural carbohydrates in the cambium of mature conifer trees reflects radial growth demands. Tree Physiol. 33(9), 913-923. https://doi.org/10.1093/treephys/tpt075.

Skene, D.S., 1969. The period of time taken by cambial derivatives to grow and differentiate into tracheids in Pinus radiata D. Don. Ann. Bot. 33(2), 253-262. https://doi.org/10.1093/oxfordjournals.aob.a084280. 
Sperry, J.S., Hacke, U.G., Pittermann, J., 2006. Size and function in conifer tracheids and angiosperm vessels. Am. J. Bot. 93(10), 1490-1500. https://doi.org/10.3732/ajb.93.10.1490.

Stine, A.R., Huybers, P., 2017. Implications of Liebig's law of the minimum for treering reconstructions of climate. Environ. Res. Lett. 12(11), 114018. https://doi.org/10.1088/1748-9326/aa8cd6.

Sun, Y., Wang, L., Yin, H., 2016. Influence of climatic factors on tree-ring maximum latewood density of Picea schrenkiana in Xinjiang, China. Front. Earth Sci. 10(1), 126-134. https://doi.org/10.1007/s11707-015-0507-6.

Sviderskaya, I.V., Soukhovolsky, V.G., Radosteva, E.Y., Kirdyanov, A.V., 2011. Model estimation of optimal ratio between cell wall thickness and lumen size for tracheids of conifers in temperate zone. J. Sib. Fed. Univ. Biol. 4(2), 183-196 (in Russian).

Uggla, C., Mellerowicz, E.J., Sundberg, B., 1998. Indole-3-acetic acid controls cambial growth in Scots pine by positional signaling. Plant Physiol. 117(1), 113-121. https://doi.org/10.1104/pp.117.1.113.

Uggla, C., Magel, E., Moritz, T., Sundberg, B., 2001. Function and dynamics of auxin and carbohydrates during earlywood/latewood transition in Scots pine. Plant Physiol. 125(4), 2029-2039.

Vaganov, E.A., Terskov, I.A., 1977. Tree growth analysis by tree-ring structure. Nauka, Novosibirsk, 98 pp. (in Russian).

Vaganov, E.A., Shashkin, A.V., Sviderskaya, L.V., Vysotskaya, L.G., 1985. Histometric analysis of woody plant growth. Nauka, Novosibirsk, 102 pp. (in Russian).

Vaganov, E.A., Hughes, M.K., Shashkin, A.V., 2006. Growth dynamics of conifer tree rings: Images of past and future environments. Springer-Verlag, Berlin; Heidelberg, 358 pp.

Vysotskaya, L.G., Vaganov, E.A., 1989. Components of the variability of radial cell size in tree rings of conifers. IAWA J. 10(4), 417-426. https://doi.org/10.1163/2294193290001134.

Wareing, P.F., Phillips, I.D.J., 1970. The control of growth and differentiation in plants. Pergamon Press, Oxford; New York; Toronto; Sydney; Breunschweig, 308 pp.

Wodzicki, T.J., 1971. Mechanism of xylem differentiation in Pinus silvestris L. J. Exp. Bot. 22(3), 670-687. https://doi.org/10.1093/jxb/22.3.670.

Yasue, K., Funada, R., Kobayashi, O., Ohtani, J., 2000. The effects of tracheid dimensions on variations in maximum density of Picea glehnii and relationships to climatic factors. Trees 14(4), 223-229. https://doi.org/10.1007/PL00009766. 
Zeng, Q., Rossi, S., Yang, B., 2017. Effects of age and size on xylem phenology in two conifers of Northwestern China. Front. Plant Sci. 8, 2264. https://dx.doi.org/10.3389/fpls.2017.02264.

Zhang, M., Ji, C., Zhu, J., Wang, X., Wang, D., Han, W., 2017. Comparison of wood physical and mechanical traits between major gymnosperm and angiosperm tree species in China. Wood Science and Technology 51(6), 1405-1419. https://doi.org/10.1007/s00226017-0954-1.

Zhang, J., Gou, X., Pederson, N., Zhang, F., Niu, H., Zhao, S., Wang, F., 2018. Cambial phenology in Juniperus przewalskii along different altitudinal gradients in a cold and arid region. Tree Physiol. 38(6), 840-852. https://doi.org/10.1093/treephys/tpx 160.

Ziaco, E., Biondi, F., 2016. Tree growth, cambial phenology, and wood anatomy of limber pine at a Great Basin (USA) mountain observatory. Trees 30(5), 1507-1521. https://doi.org/10.1007/s00468-016-1384-7.

Zobel, B.J., van Buijtenen, J.P., 1989. Wood variation - its causes and control. Springer-Verlag, Berlin, 363 pp.

Zobel, B.J., Jett, J.B., 2012. Genetics of wood production. Springer-Verlag, Berlin, $337 \mathrm{pp}$. 


\section{Table 1}

Primary statistics of measured individual series and local chronologies of Picea obovata tree ring anatomical traits. Dmax, maximal radial cell diameter; Dmean, mean radial cell diameter; CWTmax, maximal cell wall thickness; Pos, normalized to 15 cells per ring position of the transition to thick-walled cells. Numerator is mean \pm SD value $(\mu \mathrm{m})$; denominator is coefficient of variation $(\%)$.

\begin{tabular}{|c|c|c|c|c|c|c|}
\hline \multirow{2}{*}{ Site } & \multicolumn{5}{|c|}{ Individual series } & \multirow{2}{*}{$\begin{array}{l}\text { Local } \\
\text { chronologies }\end{array}$} \\
\hline & 1 & 2 & 3 & 4 & 5 & \\
\hline \multicolumn{7}{|c|}{ Dmax } \\
\hline \multirow{2}{*}{ HIGH } & $37.7 \pm 2.0$ & $\underline{35.6 \pm 3.1}$ & $\underline{41.0 \pm 3.9}$ & $\underline{40.2 \pm 2.7}$ & $\underline{45.0 \pm 2.3}$ & $\underline{39.9 \pm 1.6}$ \\
\hline & $5.4 \%$ & $8.7 \%$ & $9.6 \%$ & $6.7 \%$ & $5.1 \%$ & $3.9 \%$ \\
\hline \multirow{2}{*}{ MID } & $\underline{39.5 \pm 2.7}$ & $\underline{37.9 \pm 3.5}$ & $\underline{34.8 \pm 1.9}$ & $\underline{37.3 \pm 2.9}$ & $\underline{40.4 \pm 2.6}$ & $\underline{37.9 \pm 1.9}$ \\
\hline & $6.8 \%$ & $9.1 \%$ & $5.4 \%$ & $7.7 \%$ & $6.4 \%$ & $5.1 \%$ \\
\hline \multirow{2}{*}{ LOW } & $\underline{45.5 \pm 3.7}$ & $\underline{43.2 \pm 5.5}$ & $\underline{41.2 \pm 2.8}$ & $\underline{45.1 \pm 4.3}$ & $\underline{42.8 \pm 3.3}$ & $\underline{43.6 \pm 2.9}$ \\
\hline & $8.2 \%$ & $12.6 \%$ & $6.8 \%$ & $9.5 \%$ & $7.7 \%$ & $6.7 \%$ \\
\hline \multicolumn{7}{|c|}{ Dmean } \\
\hline \multirow{2}{*}{ HIGH } & $26.6 \pm 1.4$ & $\underline{24.1 \pm 2.1}$ & $26.1 \pm 2.9$ & $27.9 \pm 2.0$ & $\underline{32.3 \pm 1.6}$ & $\underline{27.4 \pm 1.5}$ \\
\hline & $5.5 \%$ & $8.6 \%$ & $11.0 \%$ & $7.3 \%$ & $4.9 \%$ & $5.6 \%$ \\
\hline \multirow{2}{*}{ MID } & $28.3 \pm 2.3$ & $\underline{27.1 \pm 2.3}$ & $\underline{25.8 \pm 1.5}$ & $\underline{28 \pm 1.8}$ & $\underline{28.9 \pm 1.7}$ & $\underline{27.6 \pm 1.4}$ \\
\hline & $8.0 \%$ & $8.6 \%$ & $5.8 \%$ & $6.6 \%$ & $6.0 \%$ & $5.1 \%$ \\
\hline \multirow{2}{*}{ LOW } & $\underline{32.7 \pm 2.4}$ & $\underline{31.1 \pm 2.9}$ & $28.5 \pm 1.6$ & $30.5 \pm 3.4$ & $30.3 \pm 2.5$ & $\underline{30.6 \pm 2}$ \\
\hline & $7.3 \%$ & $9.4 \%$ & $5.7 \%$ & $11.1 \%$ & $8.1 \%$ & $\overline{6.6 \%}$ \\
\hline \multicolumn{7}{|c|}{ CWTmax } \\
\hline \multirow{2}{*}{$\mathrm{HIGH}$} & $\underline{3.82 \pm 0.39}$ & $\underline{2.98 \pm 0.45}$ & $\underline{2.61 \pm 0.32}$ & $\underline{2.84 \pm 0.48}$ & $\underline{4.61 \pm 0.85}$ & $\underline{3.37 \pm 0.34}$ \\
\hline & $10.2 \%$ & $15.2 \%$ & $12.4 \%$ & $16.8 \%$ & $18.5 \%$ & $10.1 \%$ \\
\hline \multirow{2}{*}{ MID } & $\underline{4.44 \pm 0.85}$ & $\underline{4.54 \pm 0.80}$ & $\underline{4.98 \pm 0.55}$ & $\underline{4.68 \pm 0.70}$ & $\underline{4.63 \pm 0.80}$ & $\underline{4.61 \pm 0.53}$ \\
\hline & $19.0 \%$ & $17.6 \%$ & $11.1 \%$ & $15.0 \%$ & $17.2 \%$ & $11.5 \%$ \\
\hline \multirow{2}{*}{ LOW } & $\underline{4.53 \pm 0.93}$ & $\underline{3.93 \pm 0.71}$ & $\underline{4.55 \pm 0.97}$ & $\underline{4.63 \pm 0.69}$ & $\underline{5.40 \pm 0.53}$ & $\underline{4.57 \pm 0.45}$ \\
\hline & $20.6 \%$ & $18.2 \%$ & $21.3 \%$ & $15.0 \%$ & $9.7 \%$ & $9.9 \%$ \\
\hline \multicolumn{7}{|c|}{ Pos } \\
\hline \multirow{2}{*}{ HIGH } & $\underline{8.0 \pm 1.6}$ & $10.3 \pm 1.4$ & $\underline{9.7 \pm 1.9}$ & $9.7 \pm 1.6$ & $7.7 \pm 1.6$ & $\underline{9.1 \pm 1.0}$ \\
\hline & $19.5 \%$ & $13.5 \%$ & $19.4 \%$ & $16.3 \%$ & $\overline{21.0 \%}$ & $\overline{11.3 \%}$ \\
\hline \multirow{2}{*}{ MID } & $\underline{8.2 \pm 1.4}$ & $\underline{8.4 \pm 1.3}$ & $\underline{7.1 \pm 1.0}$ & $\underline{7.4 \pm 1.5}$ & $\underline{8.2 \pm 1.5}$ & $\underline{7.9 \pm 0.9}$ \\
\hline & $16.7 \%$ & $\overline{15.4 \%}$ & $\overline{14.7 \%}$ & $\overline{20.6 \%}$ & $\overline{17.6 \%}$ & $\overline{11.5 \%}$ \\
\hline \multirow{2}{*}{ LOW } & $\underline{8.6 \pm 1.3}$ & $\underline{9.3 \pm 2.1}$ & $\underline{8.3 \pm 1.9}$ & $\underline{8.0 \pm 1.4}$ & $\underline{7.4 \pm 1.7}$ & $\underline{8.3 \pm 1.0}$ \\
\hline & $15.2 \%$ & $22.8 \%$ & $23.2 \%$ & $17.2 \%$ & $22.6 \%$ & $11.7 \%$ \\
\hline
\end{tabular}




\section{Table 2}

Correlations between local chronologies of the same Picea obovata tree ring trait but different sites. N, cell number; TRW, tree ring width raw chronology calculated from five trees used for anatomical measurements; TRWstd, tree ring width indexed (standard) chronology calculated from full local sample; Dmax, maximal radial cell diameter; Dmean, mean radial cell diameter; CWTmax, maximal cell wall thickness; Pos, normalized to 15 cells per ring position of the transition to thick-walled cells.

\begin{tabular}{lccccccc}
\hline Sites & N & TRW & TRWstd & Dmax & Dmean & CWTmax & Pos \\
\hline LOW / MID & 0.11 & 0.17 & 0.16 & $0.58^{*}$ & $0.50^{*}$ & -0.01 & 0.09 \\
MID / HIGH & $-0.30^{*}$ & -0.24 & $0.41^{*}$ & 0.22 & $0.36^{*}$ & $0.54^{*}$ & $0.62^{*}$ \\
LOW / HIGH & 0.25 & 0.26 & 0.16 & 0.11 & 0.27 & 0.02 & 0.28 \\
\hline$P<0$ & & & & & & &
\end{tabular}




\section{Table 3}

Correlations between local chronologies of different Picea obovata tree ring traits within each site. N, cell number; TRW, tree ring width raw chronology calculated from five trees used for anatomical measurements; TRWstd, tree ring width indexed (standard) chronology calculated from full local sample; Dmax, maximal radial cell diameter; Dmean, mean radial cell diameter; CWTmax, maximal cell wall thickness; Pos, normalized to 15 cells per ring position of the transition to thick-walled cells.

\begin{tabular}{|c|c|c|c|c|c|c|}
\hline $\begin{array}{l}\text { Tree ring } \\
\text { trait }\end{array}$ & $\mathrm{N}$ & TRW & TRWstd & Dmax & Dmean & Pos \\
\hline \multicolumn{7}{|c|}{ HIGH } \\
\hline TRW & $0.98^{*}$ & & & & & \\
\hline TRWstd & $0.59^{*}$ & $0.67^{*}$ & & & & \\
\hline Dmax & 0.22 & $0.33^{*}$ & $0.44^{*}$ & & & \\
\hline Dmean & $0.34^{*}$ & $0.50^{*}$ & $0.65^{*}$ & $0.79^{*}$ & & \\
\hline Pos & -0.07 & -0.07 & -0.20 & 0.14 & 0.10 & \\
\hline CWTmax & $0.36^{*}$ & $0.36^{*}$ & $0.43^{*}$ & -0.04 & 0.08 & $-0.76^{*}$ \\
\hline \multicolumn{7}{|l|}{ MID } \\
\hline TRW & $0.97^{*}$ & & & & & \\
\hline TRWstd & $0.84^{*}$ & $0.91^{*}$ & & & & \\
\hline Dmax & $0.47^{*}$ & $0.62^{*}$ & $0.67^{*}$ & & & \\
\hline Dmean & $0.53^{*}$ & $0.72^{*}$ & $0.75^{*}$ & $0.86^{*}$ & & \\
\hline Pos & $-0.35^{*}$ & $-0.34^{*}$ & $-0.35^{*}$ & -0.21 & -0.16 & \\
\hline CWTmax & $0.56^{*}$ & $0.57^{*}$ & $0.58^{*}$ & $0.41^{*}$ & $0.39^{*}$ & $-0.69^{*}$ \\
\hline \multicolumn{7}{|c|}{ LOW } \\
\hline TRW & $0.98^{*}$ & & & & & \\
\hline TRWstd & $0.86^{*}$ & $0.85^{*}$ & & & & \\
\hline Dmax & 0.24 & $0.38^{*}$ & 0.19 & & & \\
\hline Dmean & $0.53^{*}$ & $0.67^{*}$ & $0.48^{*}$ & $0.84^{*}$ & & \\
\hline Pos & -0.22 & -0.14 & -0.19 & 0.08 & 0.05 & \\
\hline CWTmax & -0.01 & -0.08 & -0.10 & -0.10 & -0.05 & $-0.58^{*}$ \\
\hline
\end{tabular}

${ }^{*} P<0.05$. 


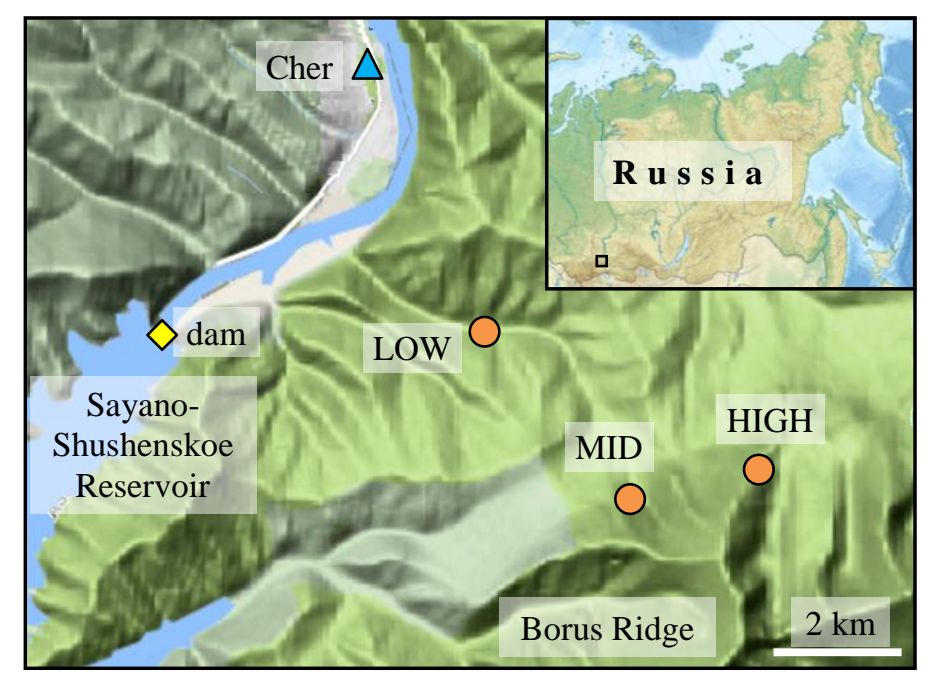

Fig. 1. Map of the study area. Cheryomushki weather station is marked with triangle; sampling sites are marked with circles; dam of the Sayano-Shushenskoe Reservoir is marked with diamond. Small map in right top corner shows study area location in the Asian part of Russia 


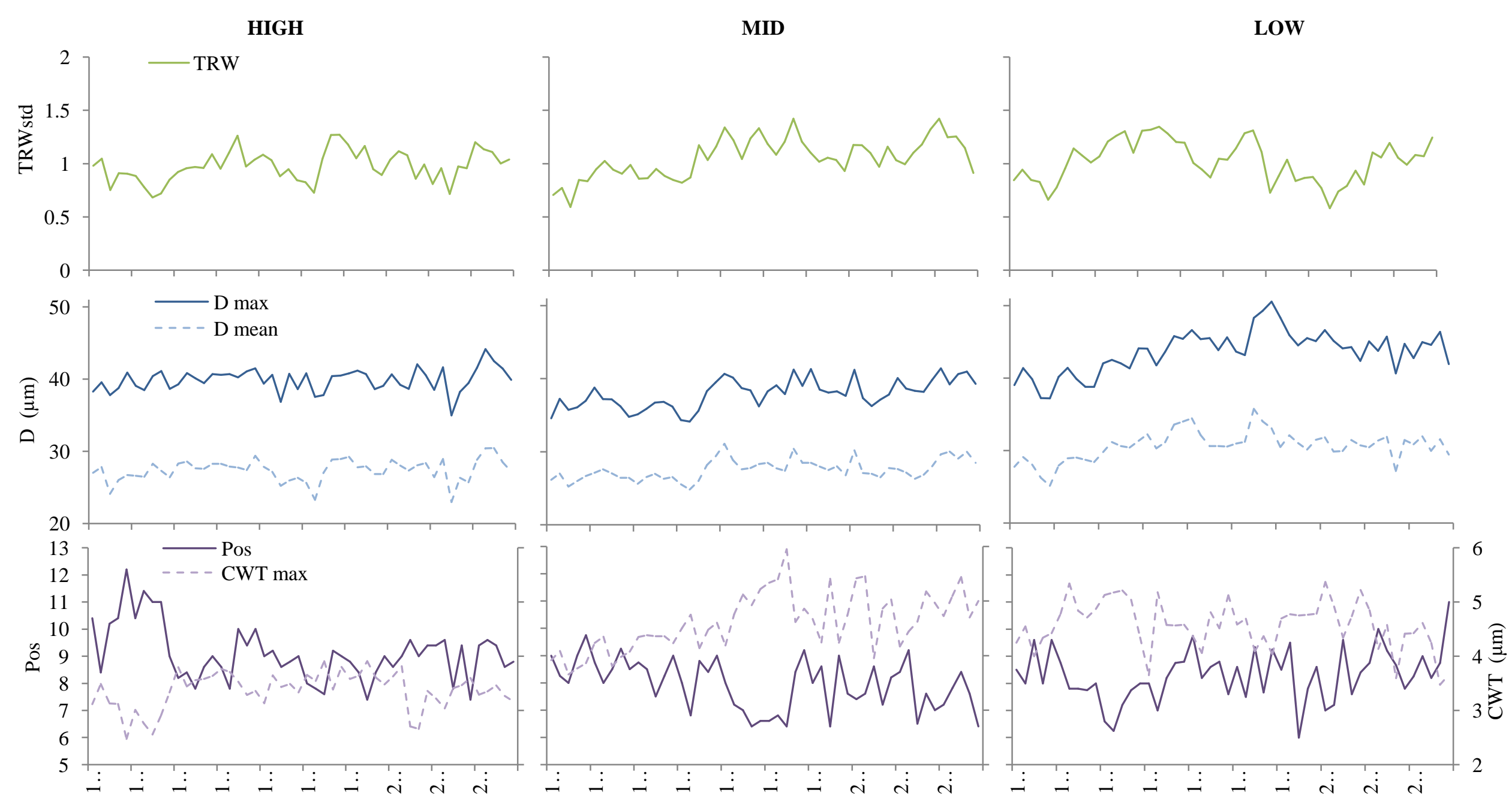

Time (year)

Fig. 2. Local chronologies of Picea obovata tree ring traits: tree-ring width (TRW; lines) indexed (standard) series as result of cell production in the top row of graphs; maximal (Dmax; dark lines) and mean (Dmean; light lines) cell radial diameters as results of cell expansion in the middle row; relative position of the transition to thick-walled cells (Pos; dark lines) and maximal cell wall thickness (CWTmax; light lines) as results of cell wall deposition in the bottom row 

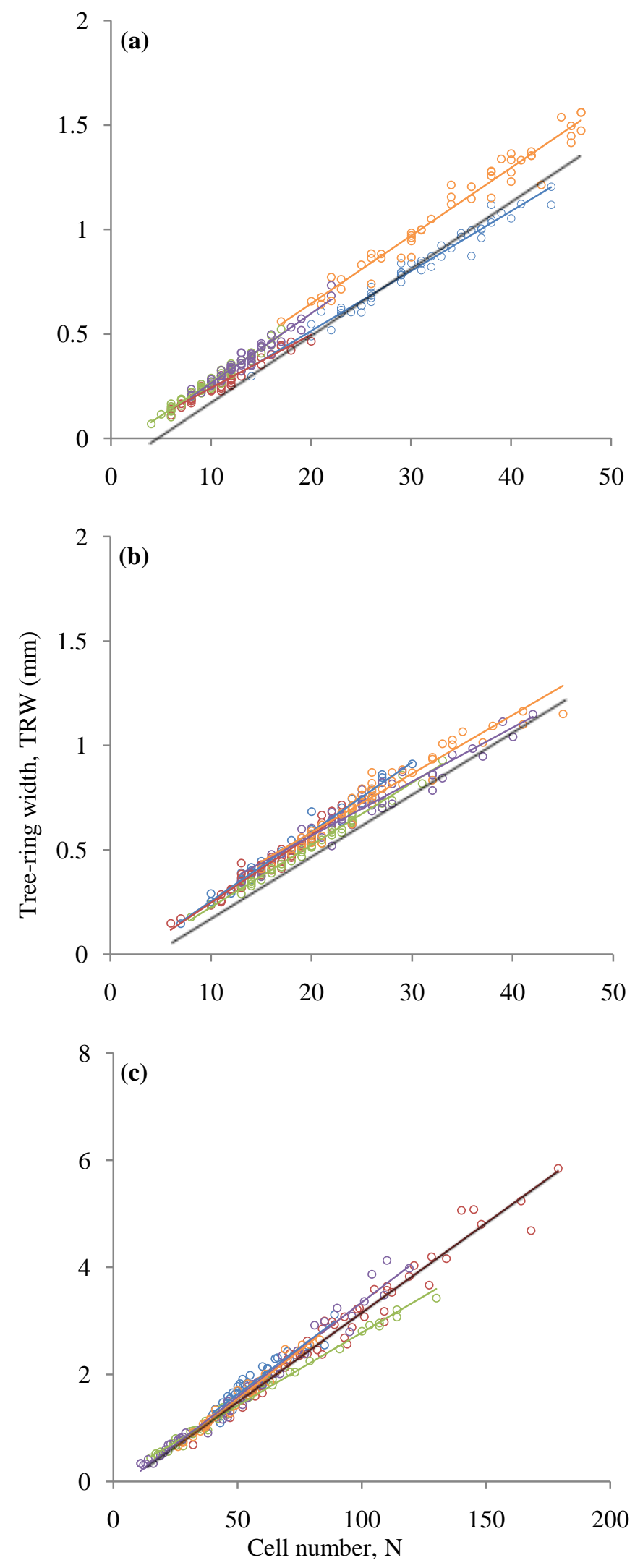

Fig. 3. Relationship between cell number (N) and tree ring width (TRW) of Picea obovata at (a) HIGH, (b) MID, and (c) LOW sites. Lines represent TRW(N) linear regressions for sites (black lines) and individual tree series (colored lines), dots represent actual measured rings (individual trees are shown with different colors). Statistics of TRW(N) linear regressions are shown in Supporting information, Table S1 

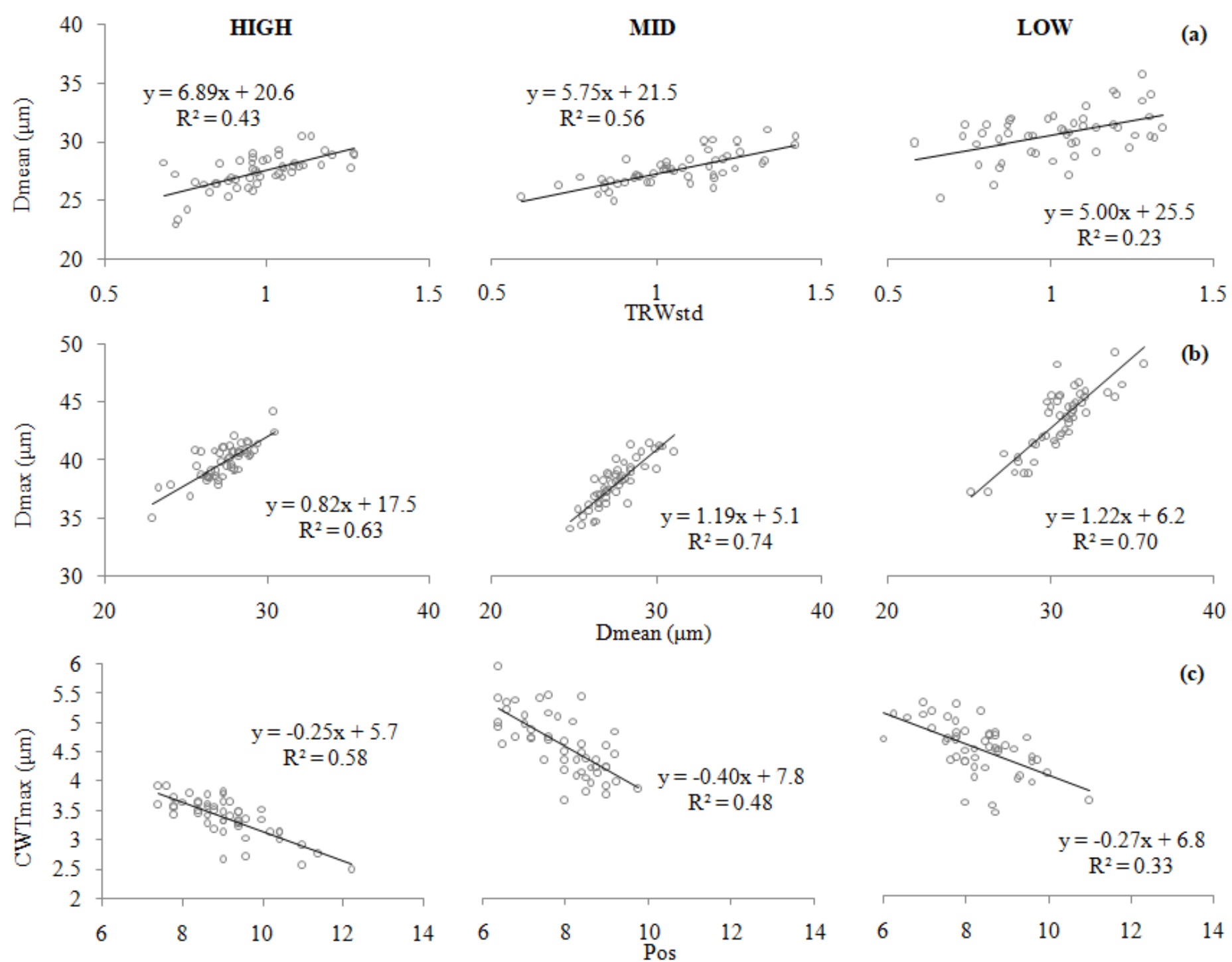

(c)
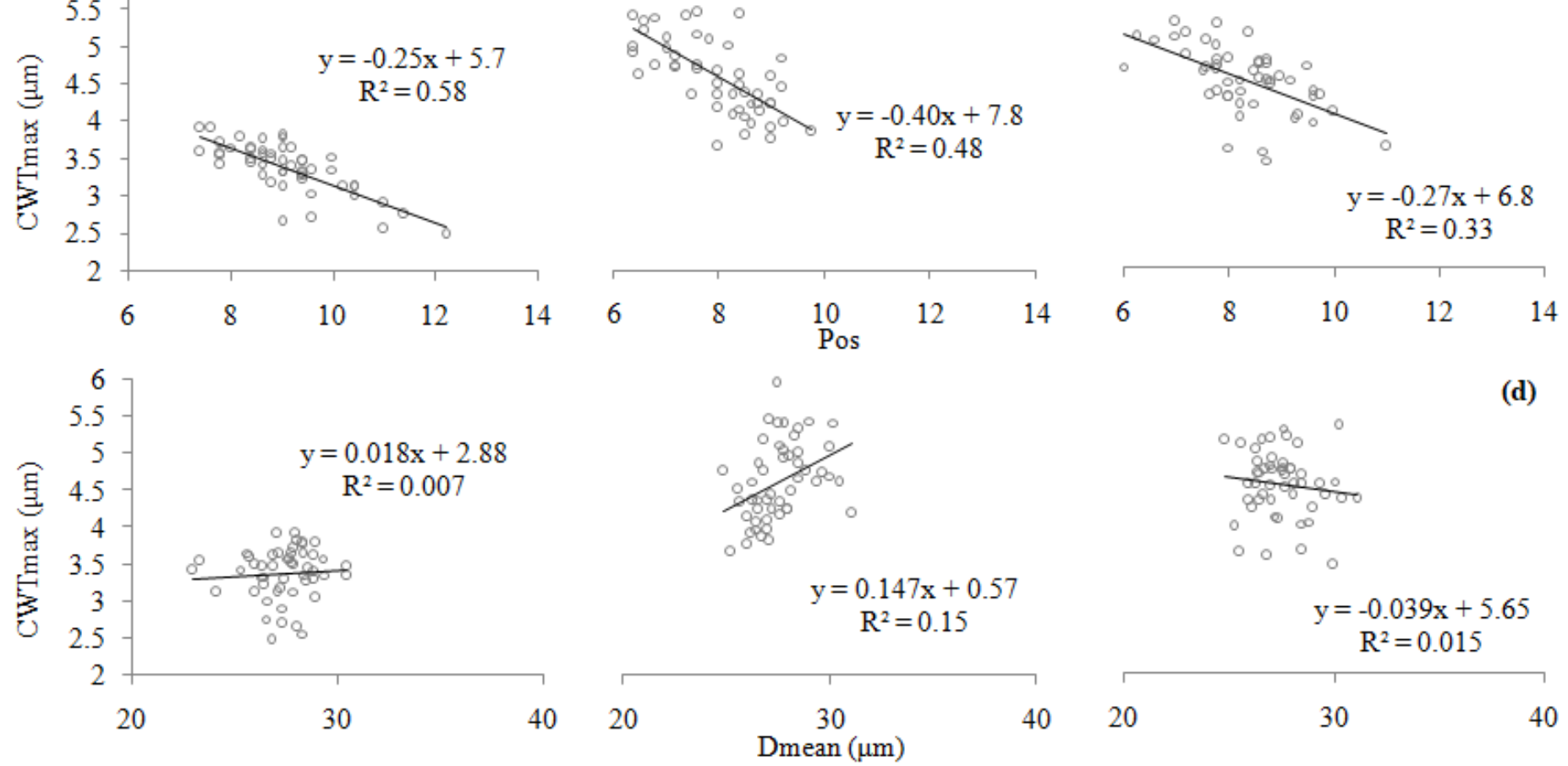

(d)

Fig. 4. Scatter plots of relationships between Picea obovata tree ring traits within each site over 1965-2014: (a) indexed (standard) tree-ring width (TRWstd) and mean radial cell diameter (Dmean); (b) mean (Dmean) and maximal (Dmax) radial cell diameters; (c) relative position of transition to thick-walled cells (Pos) and maximal cell wall thickness (CWTmax); (d) mean radial cell diameter (Dmean) and maximal cell wall thickness (CWTmax) 


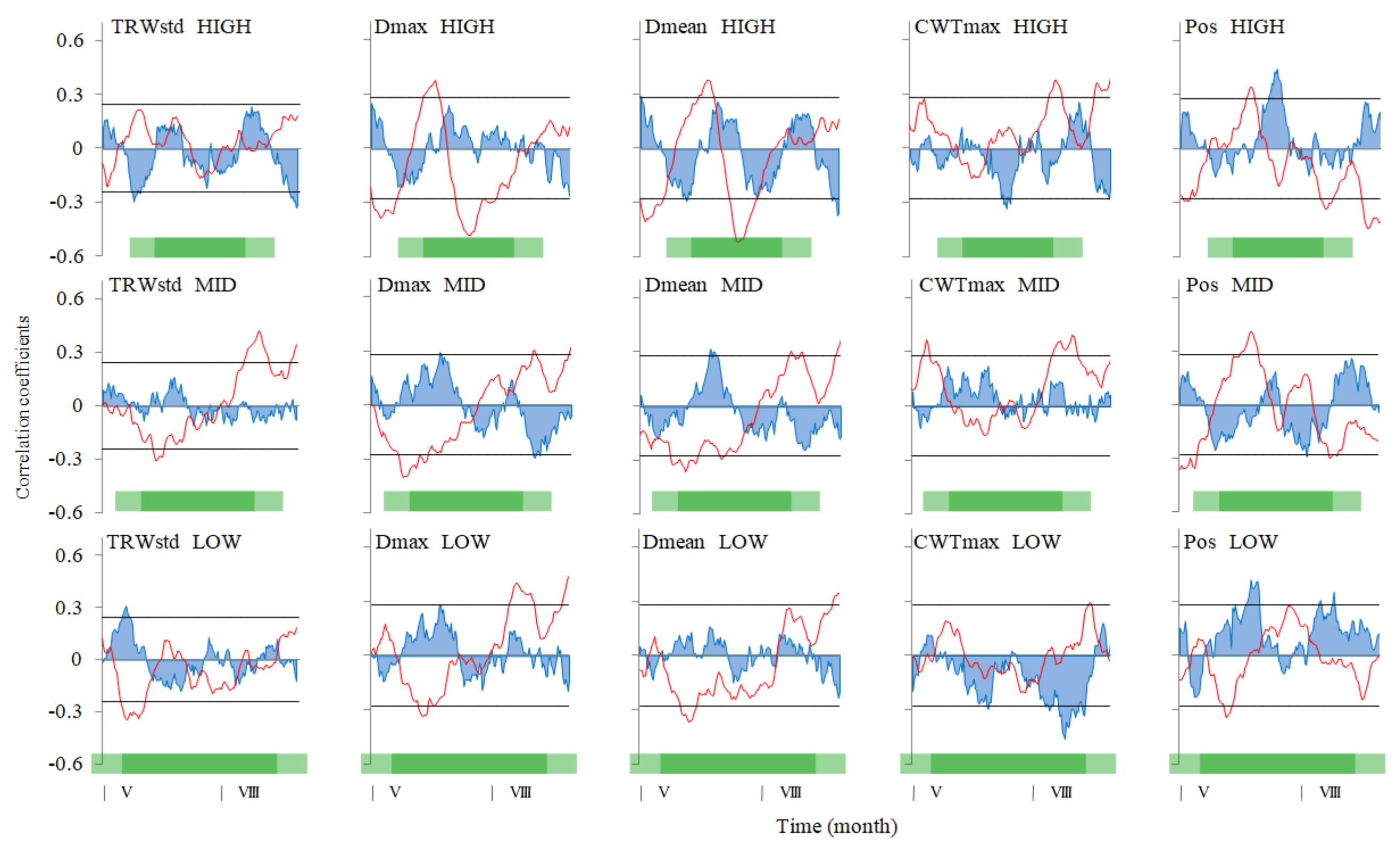

Fig. 5. Correlations between Picea obovata tree ring traits' local chronologies and moving series of temperature (lines) and precipitation (areas) calculated with 21-day window and 1-day step within the season (see Materials and Methods for details). Significance level $P=0.05$ is shown with dashed straight lines. Average timing of seasons when temperatures are above $+5^{\circ} \mathrm{C}$ and $+10^{\circ} \mathrm{C}$ are shown at the bottom of each panel with light and dark horizontal bars respectively 

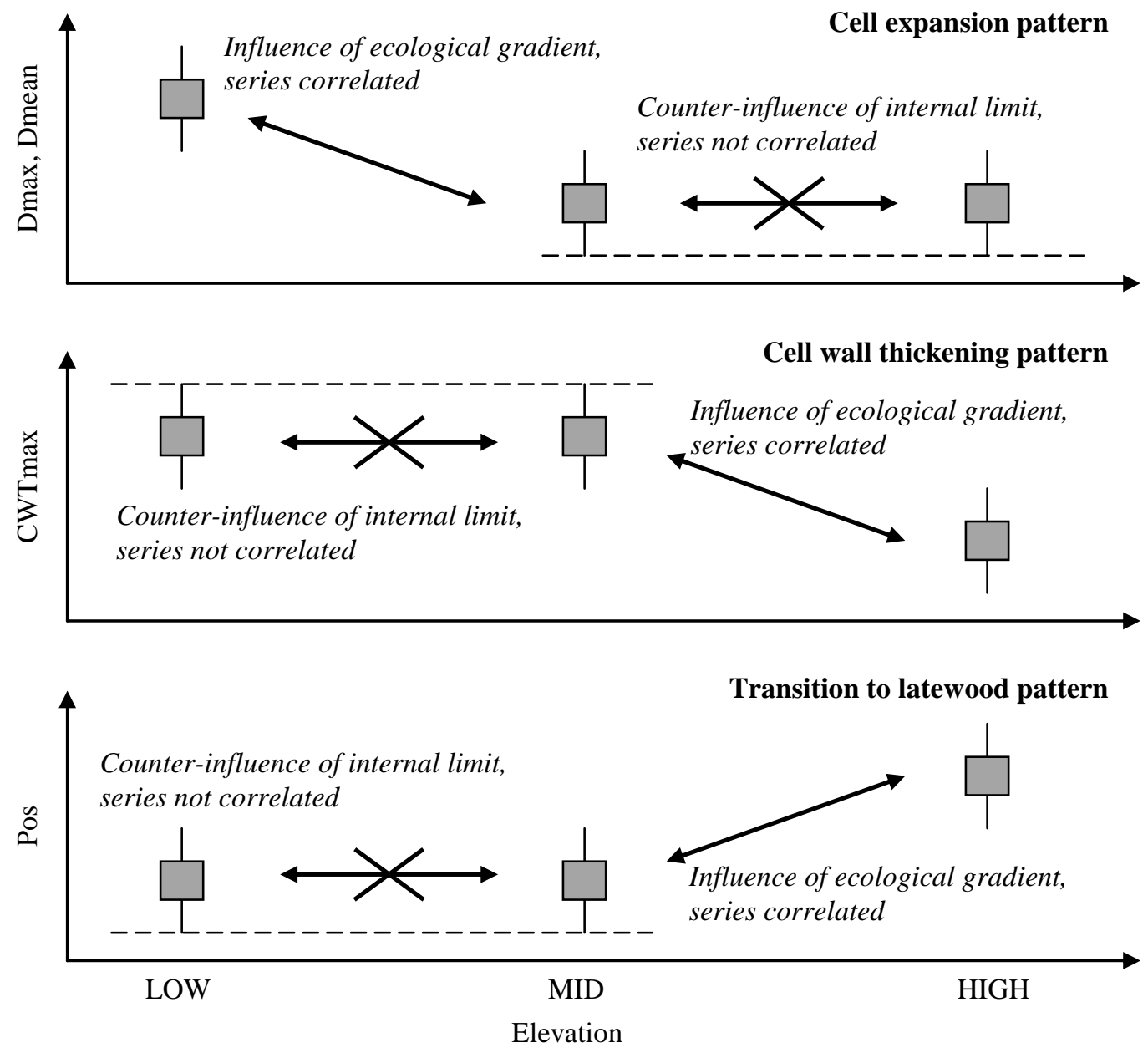

Fig. 6. Patterns in values of Picea obovata tree ring anatomical traits and in relationships between them along the elevational gradient 


\section{Siberian spruce tree ring anatomy: imprint of development processes and their high-temporal environmental regulation}

Elena A. Babushkina, Liliana V. Belokopytova, Dina F. Zhirnova, Eugene A. Vaganov

\section{Supporting information}

\section{Table S1}

Evaluations of Picea obovata mean radial cell diameter Dmean from TRW(D) linear regressions for series of individual trees separately and for local sample as a whole. $\mathrm{N}$, cell number; TRW, tree ring width calculated from anatomical measurements.

\begin{tabular}{|c|c|c|c|c|c|c|}
\hline \multirow{2}{*}{ Statistics } & \multicolumn{5}{|c|}{ Individual series } & \multirow{2}{*}{$\begin{array}{l}\text { Local } \\
\text { sample }\end{array}$} \\
\hline & 1 & 2 & 3 & 4 & 5 & \\
\hline $\mathrm{HIGH}$ & & & & & & \\
\hline $\mathrm{R}^{2}$ of $\mathrm{TRW}(\mathrm{N})$ linear regression & 0.966 & 0.937 & 0.967 & 0.946 & 0.964 & 0.968 \\
\hline $\begin{array}{l}\text { estimated Dmean }(\mu \mathrm{m}) \\
\quad \text { MID }\end{array}$ & 28.6 & 25.6 & 32.0 & 33.3 & 32.5 & 31.8 \\
\hline $\mathrm{R}^{2}$ of $\mathrm{TRW}(\mathrm{N})$ linear regression & 0.982 & 0.948 & 0.985 & 0.941 & 0.941 & 0.960 \\
\hline $\begin{array}{l}\text { estimated Dmean }(\mu \mathrm{m}) \\
\text { LOW }\end{array}$ & 33.2 & 32.4 & 29.8 & 25.9 & 28.1 & 29.4 \\
\hline $\begin{array}{l}\mathrm{R}^{2} \text { of } \mathrm{TRW}(\mathrm{N}) \text { linear regression } \\
\text { estimated Dmean }(\mu \mathrm{m})\end{array}$ & $\begin{array}{l}0.904 \\
34.7\end{array}$ & $\begin{array}{l}0.954 \\
33.4\end{array}$ & $\begin{array}{l}0.993 \\
27.3\end{array}$ & $\begin{array}{l}0.980 \\
35.4\end{array}$ & $\begin{array}{l}0.981 \\
36.4\end{array}$ & $\begin{array}{l}0.968 \\
32.5\end{array}$ \\
\hline
\end{tabular}

\section{Table S2}

Mean correlation coefficients of Picea obovata tree ring traits' individual series with their local chronologies. Each individual series was correlated with specifically calculated local chronology where this individual series is omitted. N, cell number; TRW, tree ring width; TRWstd, indexed (standard) tree ring width; Dmax, maximal radial cell diameter; Dmean, mean radial cell diameter; CWTmax, maximal cell wall thickness; Pos, normalized to 15 cells per ring position of the transition to thick-walled cells.

\begin{tabular}{lccccccc}
\hline \multicolumn{1}{c}{ Site } & $\mathrm{N}$ & TRW $^{\mathrm{a}}$ & TRWstd $^{\mathrm{b}}$ & Dmax & Dmean & CWTmax & Pos \\
\hline HIGH & $0.45^{*}$ & $0.40^{*}$ & $0.49^{*}$ & $0.59^{*}$ & $0.60^{*}$ & $0.45^{*}$ & $0.41^{*}$ \\
MID & $0.46^{*}$ & $0.45^{*}$ & $0.56^{*}$ & $0.52^{*}$ & $0.53^{*}$ & $0.49^{*}$ & $0.46^{*}$ \\
LOW & $0.58^{*}$ & $0.59^{*}$ & $0.58^{*}$ & $0.51^{*}$ & $0.61^{*}$ & $0.48^{*}$ & $0.40^{*}$ \\
\hline
\end{tabular}

${ }^{*} P<0.05$

${ }^{a}$ Correlations between individual raw TRW series and raw TRW chronology calculated from five trees used for anatomical measurements.

${ }^{\mathrm{b}}$ Correlations between the same individual raw TRW series and indexed (standard) TRW chronology calculated from full local sample. 


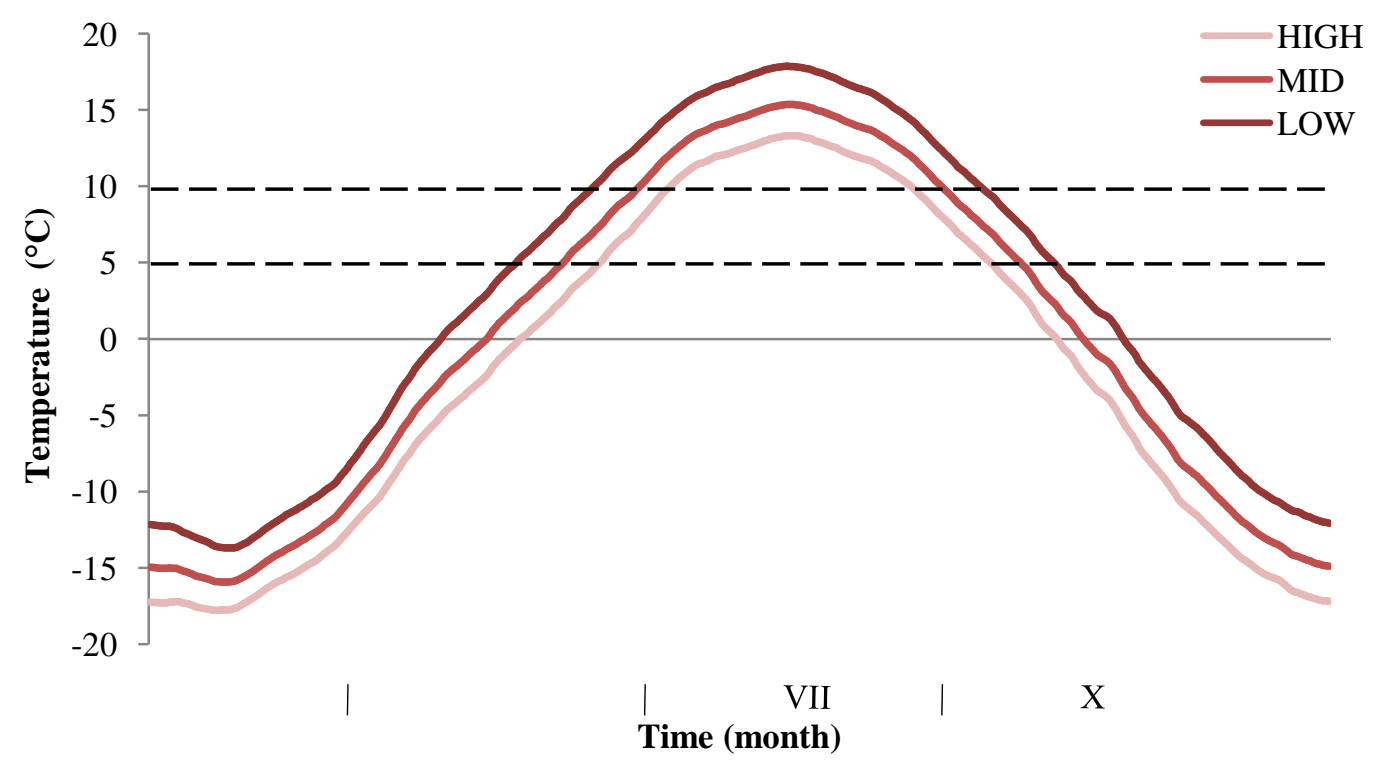

Fig. S1. Estimation of an average intra-annual temperature dynamics at sampling sites. Calculation was performed from 1965-2014 daily climatic data of Cheryomushki (330 m a.s.l.) and Olenya Rechka (1400 m a.s.l.) weather stations with linear interpolation accordingly to the elevations of stations and sampling sites. Dashed lines show temperature thresholds of +5 and $+10^{\circ} \mathrm{C}$.
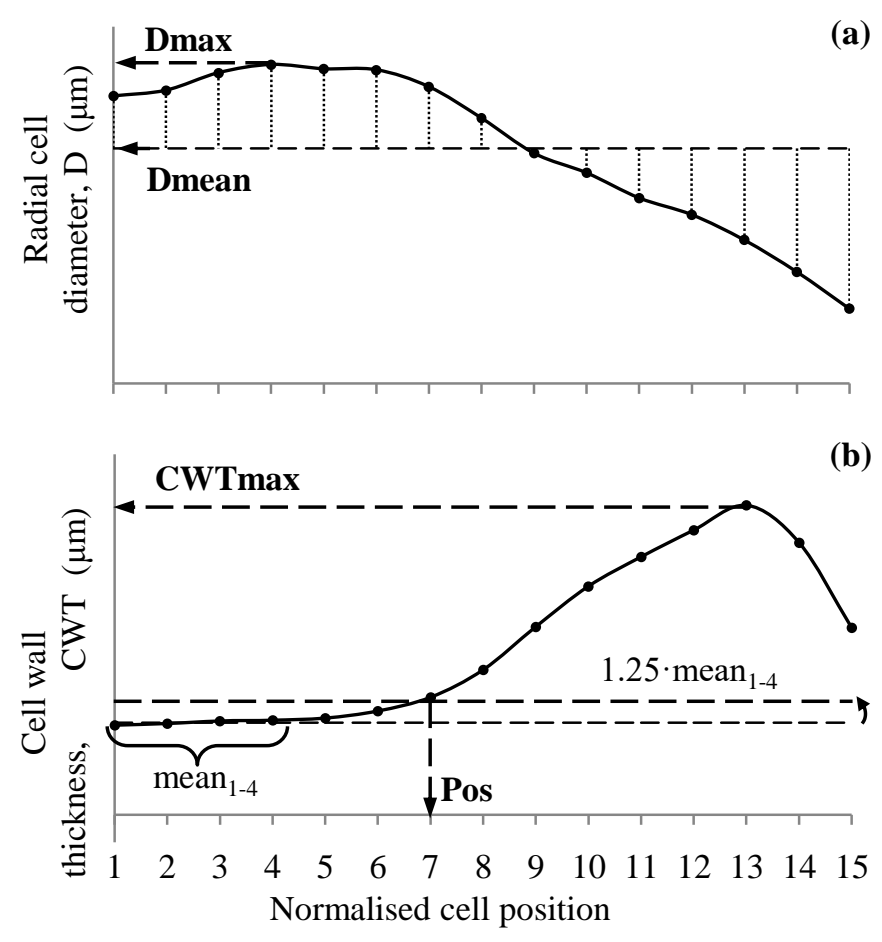

Fig. S2. Scheme of tree ring anatomical traits' calculation from normalised tracheidograms of (a) radial diameter and (b) cell wall thickness on example of randomly selected tree ring 